\title{
Urfausto, Urfasto. Una leve aproximación al mito, una escueta recuperación de éste -al cumplirse cien años de la Gran Guerra-, en su vínculo con el poder
}

\section{Urfausto, Urfasto. A slight approach to myth, a brief disclosure of its concept and its connection to power, on the occasion of the $100^{\text {th }}$ anniversary of the Great War}

\section{Cucho VAlCÁRcel}

Departamento de Música

\author{
Instituto León Felipe de Torrejón de Ardoz (Madrid) \\ Aula de Música de la Fundación UAM \\ sementeira@hotmail.com
}

\section{URFAXSTO}

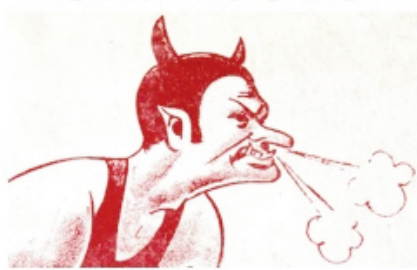

[PARA MAYORES DE 16 AÑOS DE EDAD] ${ }^{1}$

\section{Resumen}

Este breve ensayo tiene su origen en la versión escénica que, con el mismo título, el autor ha preparado: una visión e interpretación particulares del mito de Fausto. La exposición analítica, que se ofrece, intenta abordar los aspectos funda-

\footnotetext{
1 Imagen de la tragicomedia Urfausto, del autor de este artículo, y que es un extracto de la portada del libro de Knight, R., El Baloncesto, Madrid, Federación española de Baloncesto, 1971.
} 
mentales, y las pasiones humanas, que el mito aporta, reflexionando sobre éstos; también, para proponer una conclusión específica, tras el estudio de las distintas fuentes que, desde la Baja Edad Media, constituyen el acervo de uno de los mitos europeos tardíos. Igualmente, se intenta otorgar actualidad al mito, en el contexto contemporáneo; ante los acontecimientos que se suceden, en las relaciones con el poder -y de «poder»-, y en el marco de lo que parece ser una «crisis» ética ¿y estética?, paralela a la sofisticada y divulgada crisis económica. Sabemos que el poder es un asunto que, todavía como un tabú, debe ser tratado con «delicadeza quirúrgica», sobre todo frente a los acreedores de algún tipo de ideología. La actualidad fáustica conecta con la idea de que es el mito el que funda la Historia; no al revés.

Palabras clave: mito, Fausto, Mefistófeles, poder, fasto, alter ego

\begin{abstract}
This brief essay originated in the scenic version which, under the same title, has been prepared by the author: a particular vision and interpretation of the myth of Faust. The analysis herein provided aims at dealing with the fundamental aspects and the human passions that the concept of myth entails, by means of a thorough reflection, in order to propose a specific conclusion following the study of various sources which, as of the late Middle Ages, comprise the acquis of one of the late European myths. It also intends to provide myth with a topical perspective within a contemporary context, in light of the events that take place, the relations with power -and "of power", and within the framework of what seems to be an ethical -and perhaps aesthetical?- crisis, in parallel with the sophisticated and widely spread economic crisis. We understand that power is an issue that, as taboo as it still is, should be addressed with "surgical sensitivity", especially in front of creditors of any type of ideologies. Faustic reality connects with the concept that myth is indeed the base of History, and not the other way around.
\end{abstract}

Keywords: myth, Faust, Mephistopheles, power, splendor, alter ego

Gonzalo A. Gómez Valcárcel

In memoriam

¡Sólo el cambio [...] permite que olvidemos que vivir es insoportable! 2 Quiero decir a la gente: mirad qué aburrida y deslustrada es vuestra vida. Lo importante es que las personas lo entiendan; si lo entienden, seguramente se inventarán una vida diferente y mejor. ${ }^{3}$

2 Lo dice Don Juan, en la obra Don Juan y Fausto, de Christian Dietrich Grabbe.

${ }^{3}$ Lo dijo Anton Chéjov. 


\section{Antecedentes e introducción}

Como no podría ser de otro modo, lo que pretendemos mostrar -tomando el mito fáustico como referencia inmediata, a partir de nuestra propuesta escénica-, proviene de nuestra tradición literaria, musical, dramática y plástica -"lo que sabemos, lo sabemos entre todos"4-, o sea una poliantea entre escritura e imagen. Intentaremos analizar los datos relevantes de un problema para hallar una respuesta $-\mathrm{y}$ nuevas preguntas, quizá-. Por eso, hemos recurrido al acervo fáustico de la literatura europea -que ofrecemos, casi, a modo de catálogo-, y nos encontramos, aparte de con un origen mítico medieval ${ }^{5}$, con Christopher Marlowe ${ }^{6}$, con Nikolas Pfitzer $^{7}$, con Friedrich Maximilian Klinger ${ }^{8}$, con Johann Wolfgang Goethe ${ }^{9}$, con

${ }^{4}$ Es una oración oída al profesor Alfredo Vicent, de la universidad Autónoma de Madrid, en el año 2004.

5 La primera publicación postmedieval, anónima renacentista, parece que fue Faustbuch (El libro de Fausto), o Volksbuch del Dr. Fausto, editado en Estrasburgo, en 1587, por Johann Spiess. No obstante, hubo un Fausto histórico, que "fue un alemán de Knittlingen que murió en torno a 1540 [...] que llevó siempre una existencia azarosa y llamativa; alumno de la reputada universidad de Wittenberg (la misma donde estudia el príncipe Hamlet), relacionado con Martín Lutero, también fue expulsado de varias ciudades alemanas, perseguido por la justicia bajo la acusación de satanismo y pederastia", como indica Molina Foix, V., «Primer y último Fausto», Fausto, 5 (2006), Madrid, OCNE, 2006, pp. 125-126.

6 The Tragical History of the Life and Death of Doctor Faustus (La trágica historia de la vida y la muerte del doctor Fausto), parece que fue escrita entre 1588 y 1589, aunque Vicente Molina Foix entiende que Marlowe se inspiró en la traducción inglesa anónima, de 1592, de La historia de la execrable vida y merecida muerte del Doctor John Faustus, lo que vemos como algo contradictorio -además, también con respecto a la coincidencia, de este último título, con el de la obra de Nikolas Pfitzer, fechada en 1674-. En todo caso, Molina Foix menciona que la fecha del estreno de la obra de Marlowe "se aventura" en torno a 1593. Puede verse en Molina Foix 2006, op. cit. (nota 5), p. 126. También, Rafael Argullol se refiere a la obra de Marlowe como surgida "cinco años después" del Faustbuch de 1587, como puede leerse en Argullol, R., «Fausto, siglo XXI», El País, Madrid, El País, 19 de enero de 2014, p. 39. Además, encontramos que la edición londinense, de la obra de Marlowe, es de 1620. Para mayor contradicción, se ha establecido que, Christopher Marlowe, vivió entre 1564 y 1593, aunque algunas investigaciones estiman que inventó su propia muerte: apuñalado en una taberna -como le sucede a Valentín, hermano de Margarita, en el film Fausto, de Alexander Sokurov-, pues estaba siendo perseguido por las autoridades. Se supone que huyó a Italia y que siguió escribiendo bajo el seudónimo de William Shakespeare, y, tal vez por ello, las obras italianas atribuidas a Shakespeare (Otello, Romeo y Julieta, El mercader de Venecia) hayan podido ser escritas por Marlowe, ya que hay quien presume que Shakespeare nunca estuvo en Italia. Las obras, narradas en esta geografía, aportan detalles que sólo podría dar alguien que hubiera vivido allí. Por tanto, la fecha de desaparición de Marlowe, como la autoría de algunas obras de Shakespeare, habría que tomarlas con precaución, lo que, a su vez, podemos inscribir en el misterio mismo de «algo» fáustico. Por otra parte, para ahondar en el misterio, Harold Bloom dice, y en cuanto a la influencia literaria, que "Shakespeare devoró a Christopher Marlowe", como puede leerse en Bloom, H., «Fuego escénico», El Cultural, Madrid, El Mundo, 6 de enero de 2012, p. 13.

7 Das ärgerliche Leben und schreckliche Ende des vielberüchtigten Ertz-Schwartzkünstlers Johannis Fausti (La historia de la execrable vida y merecida muerte del Doctor John Faustus) (1674) 
Christian Dietrich Grabbe ${ }^{10}$, con Nicolaus Lenau ${ }^{11}$, con Gérard de Nerval ${ }^{12}$, con José de Espronceda13, con Juan Valera14, con Ivan Turguéniev, con Mijaíl Bulgákov ${ }^{15}$, con Thomas Mann16, con Paul Valéry, con Fernando Pessoa, entre muchos otros. También, hemos bebido de las fuentes, directas e indirectas, de la fáustica insistencia musical17; para «mirarnos» en algunos, como en Hildegard von Bingen 18, en Alfonso X ${ }^{19}$, en Emilio de' Cavalieri20, en Antoni H. Radziwill, en Johann Friedrich Reichardt, en Karl Friedrich Zelter, en Johann Karl G. Loewe, en Franz Schubert ${ }^{21}$, en Albert Lortzing ${ }^{22}$, en Robert Schumann ${ }^{23}$, en Férénc Liszt ${ }^{24}$, en Richard Wagner25, en Gustav Mahler ${ }^{26}$, en Hans Erich Pfitzner, en Ferruccio

\author{
8 Fausts Leben, Taten und Höllenfahrt (Vida, hechos y condenación de Fausto) \\ 9 Faust \\ 10 Don Juan und Faust. Eine Tragödie in vier Akten (Don Juan y Fausto. Una tragedia en cuatro \\ actos) \\ 11 Faust \\ 12 Fue el traductor, al francés (1828), del Fausto de Goethe. \\ 13 El diablo mundo
}

14 «Fábula de Euforión» (1844), incluida en sus Ensayos poéticos. En esta fábula, sobre el hijo de Fausto y de Helena de Troya (Euforión), Juan Valera adapta el final del tercer acto de la segunda parte del Fausto de Goethe. Valera, además, fue traductor, al idioma castellano, de doce fragmentos del Fausto de Goethe. No fue el primero que tradujo a Goethe, pues antes lo había hecho Guillermo English, pero sí fue quien revisó esa traducción (1878). La recepción castellana, del Fausto alemán de Goethe, se había hecho, hasta entonces, a partir de la traducción francesa. Y hubo traducciones poéticas de Teodoro Llorente (1876), de Joan Maragall y Juan Esterlich, además de adaptaciones dramáticas de Adrià Gual.

15 El maestro y Margarita

16 Dr. Faustus

17 Porque nosotros, como el mismo Grabbe, nos reconocemos en lo siguiente: "creo que he disfrutado en lo posible de las honduras de la vida, de las ciencias y del arte; ya me sacié de todo aquello, sólo la música sigue impresionándome de manera mágica... porque no alcanzo a entenderla." Puede verse en Rohland de Langbehn, R., «Introducción», Don Juan y Fausto, Madrid, Cátedra, 2007, p. 26. También, podemos reconocernos en lo que, como señala Antoni Marí, dijo Goethe: "los músicos tenían una vena demoníaca más fuerte que los pintores y añadía: «La música contiene algo de demoníaco; es tan elevada que ningún entendimiento puede comprenderla, y tiene un poder que lo domina todo y del que nadie puede ofrecer una explicación. El culto religioso no puede prescindir de ella; es una de las mejores formas de obtener un efecto milagroso en el hombre»". Puede verse en Marí, A., «El fantasma de la música», Fausto, 5 (2006), Madrid, OCNE, 2006, pp. 121-122.

18 Ordo Virtutum

19 Cantigas de santa María; especialmente, la cantiga $\mathrm{n}^{\circ}$ 130: Quen entender quiser (Quien quiera enamorarse)

20 Rappresentatione di Anima e di Corpo (Representación del Alma y del Cuerpo)

${ }^{21}$ Lieder: Gretchen am Spinnrade, D 118 (Margarita en la rueca); Szene aus Faust, D 126; Gretchen im "Zwinger", D 564

22 Don Juan und Faust (Don Juan y Fausto)

23 Szenen aus Goethes Faust (Escenas del Fausto de Goethe)

24 Eine Faust-Symphonie, S. 108 (Una sinfonía Fausto)

25 Siete composiciones sobre el Fausto de Goethe -1831-; Ein Faust Ouvertüre (Obertura para Fausto, en Re menor) -1840-. 
Busoni27, en Paul Dessau, en Lili Boulanger ${ }^{28}$, en Werner Richard Heymann ${ }^{29}$, en Art Zoyd ${ }^{30}$; incluso, en Prudencio Muñoz ${ }^{31}$. No hemos olvidado las aportaciones cinematográficas ${ }^{32}$ vinculadas con el mito, también directa o indirectamente, de Friedrich W. Murnau ${ }^{33}$, de Roman Polanski34, de Alan Parker ${ }^{35}$, de Martin Scorsese ${ }^{36}$, de La Fura dels Baus e Isidro Ortiz ${ }^{37}$, de Alexander Sokurov38; así como las teatrales y operísticas, de J. C. Bernard, de Louis Spohr39, de Charles Gounod40, de Hector Berlioz 41 , de Anton G. Rubinstein42, de Arrigo Boito43, de Jacinto Benavente ${ }^{44}$, de Igor Stravinsky ${ }^{45}$, de Orson Welles ${ }^{46}$, de Claus Peymann ${ }^{47}$, de Wolfgang Rihm ${ }^{48}$, de Götz Loepelmann ${ }^{49}$, de David Mamet ${ }^{50}$, de La Fura dels Baus $^{51}$, de otros ${ }^{52}$. No obstante, podríamos «ir» más atrás, si se quisiera, para rebuscar indicios en la Divina Commedia dantesca; además, es posible revisar la historia

26 Sinfonía $n^{\circ} 8$
27 Doktor Faust.
28 Faust et Hélène (Fausto y Helena)
29 Partitura original para el film de Friedrich W. Murnau, que contenía adaptaciones de música de Richard Wagner y de Richard Strauss.

30 Música compuesta e interpretada para el Faust cinematográfico de Murnau (1926).

31 Mefistófela

32 Como dice Augusto M. Torres, "no voy a hacer un imposible y aburrido repaso de muchas versiones cinematográficas", sino que, en nuestro caso, destacamos aquellas que nos resultaron más influyentes. Obviar Métamorphose de Faust et apparition de Marguerite et apparition de Méphistophélès (1897), de Auguste y Louis Lumière; o Damnation du Docteur Faust (1904), de Georges Méliès, no significa olvidar estas obras. Esto, y más citas, puede leerse en Torres, A., «La imposibilidad de admirar un clásico», Fausto, 5 (2006), Madrid, OCNE, 2006, p. 143. Otro asunto sería tomar como referencia el film Doctor Faustus, dirigido por Richard Burton y Nevill Coghill en 1967, y que no reconocemos como «influyente».

33 Faust - eine deutsche Volkssage

34 Rosemary's Baby (La semilla del diablo)

35 Angel Heart (El corazón del ángel)

36 The last Temptation of Christ (La última tentación de Cristo).

37 F@usto,versión 5.0

38 Fausto

39 Faust

40 Fausto

${ }^{41}$ La damnation de Faust (La condenación de Fausto)

42 El demonio

${ }^{43}$ Mefistofele

44 Mefistófela

45 Historia del soldado

46 Faustus by Christopher Marlowe (Fausto según Marlowe)

47 Faust

48 Faust und Yorick (Fausto y Yorick)

49 Urfaust, representado, como Goethe, Fausto, en el Teatro de la Abadía, en Madrid, en 1997.

50 Dr. Faustus

51 F@usto, versión 3.0

52 No haremos comentarios sobre la propuesta escénica que, en cuanto al Fausto de Goethe, presentó 
de las artes plásticas, en la que hallaremos motivos, de fáustico interés, desde El Bosco $^{53}$ hasta Helmut Newton, pasando por Eugène Delacroix, por Mariano Fortuny, por Joaquín Espalter, por Teófilo Puebla o por Gustavo Doré, como algunos ejemplos. Quizá sea este mito, Fausto -junto con el donjuanesco-, el que más haya «dado de sí», de entre todos los mitos de generación europea. ${ }^{54}$ Otras obras literarias, que acometen el asunto fáustico de modo más o menos tangencial, también nos proporcionarían un catálogo interminable; en nuestra escenificación, nos hemos servido, sólo, de algún caso más: Benito Pérez Galdós. ${ }^{55}$

Para muchos de ellos, el punto de partida pudo estar en una obra antigua de marionetas, titulada Die Höllenbraut (La novia infernal) ${ }^{56}$, que Marlowe y Goethe conocieron. ${ }^{57}$

Tomaž Pandur en el Teatro Valle-Inclán de Madrid, entre 21 de noviembre de 2014 y 11 de enero de 2015.

53 Para adentrarse e iniciarse en el estudio de la obra del pintor, en sus conexiones con el mundo de Dante, y en la influencia en otros (Hans Blumenberg), puede consultarse Fragio, A., «La ciencia en el infierno: Blumenberg y el hombre-árbol de "El jardín de las delicias"», Escritura e imagen, 6 (2010), pp. $147-173$.

54 Entre los que se encuentran, también, los mitos de Carmen y de Don Quijote. No obstante, quizá, deberíamos matizar que el mito quijotesco, el conocido por una mayoría -si obviamos a Avellaneda-, nos parece que ha sido creado por un individuo -y podría resultar oportuno, y bien recibido, que alguien desmintiera este aserto, de lo que, al final de esta nota, damos cuenta-; por un sujeto que responde a un nombre y a unos apellidos (Miguel de Cervantes Saavedra), mientras que, en los otros casos, se trataría de una tradición, de un carácter anónimo, a la que, cada autor, ha ido aportando su interpretación; ha ido incorporando su acervo y su experiencia vitales. De todas formas, esta postura tiene matices que aporta Vicente Molina Foix: "Al contrario que Alonso Quijano, el Doctor Fausto existió antes de ser creado literariamente. Pero, al igual que nuestro caballero de La Mancha, Fausto le debe su progenitura a un solo hombre", que sería Christopher Marlowe. Puede verse en Molina Foix 2006, op. cit. (nota 5), p. 125. No obstante, hay quien piensa que Alonso Quijano sí existió, como Ángel Ligero Móstoles, tal y como indica López García, M., «¿Existió Don Quijote?», Dominical, Madrid, 24 de abril de 1988, pp. 10-15 (especialmente, p. 14). Y hay quien defiende que vivió en El Toboso, en 1584. Y su «autor» no es menos, pues hay quienes dicen que Cervantes nació en Zamora, en 1549; otros, que nació en Arganda del Rey (Madrid). ¿Son misterios fáusticos?

55 Mencionado, y sabiamente estudiado, por Leyra Soriano, A. M., De Cervantes a Dalí. Escritura, imagen y paranoia, Madrid, Fundamentos, 2006, pp. 163-179. La aportación fáustica galdosiana queda labrada, indeleblemente, en la obra La sombra (1866-1867).

56 Anterior a 1587. Goethe, al parecer, había recibido de su padre, a los cuatro años de edad, un teatrillo de marionetas. Proliferaban «Faustos» novelescos de baratillo en la época, que Goethe admite haber leído durante su infancia y adolescencia, entre los que descubrió la versión de Marlowe, tal y como expone Sala Rose, R., «Una pesada roca: rastros de Fausto en la vida de Goethe», Fausto, 5 (2006), Madrid, OCNE, 2006, pp. 45-46. No debemos descuidar la actualidad que, aún hoy, tienen las producciones, efectuadas con marionetas para adultos, sobre la representación del mito.

57 Johann Wolfgang Goethe se lo hizo saber a Friedrich von Schiller, a través de una carta fechada en 1 de agosto de 1800. Esta obra de marionetas, quizá con un origen medieval, trataba de "una niña muy vanidosa, sin amor, que destruye a sus fieles amantes y en cambio firma un pacto con un extraño novio desconocido que finalmente la [(sic)] viene a buscar, como es justo, en la figura del diablo", como decía Goethe a Schiller, y como expone Rohland de Langbehn 2007, op. cit. (nota 17), pp. 67-68. El 
El desafío y la crítica, del mito de Fausto, se asientan en que nos pasamos la vida "pregonando el bien y haciendo el mal" 58 . Pero... ¿quién es Mefistófeles59?: aquel que, como dice Goethe, siempre quiere el mal y siempre practica el bien. Los hay que defienden que, "más que un diablo, parece un desenmascarador de vicios. [...] Sin embargo, también practica el mal, o mejor dicho la malicia" 60 , gracias a la que "pondrá al descubierto la ineptitud, la pereza, la irresponsabilidad, el egoísmo, la mezquindad... en fin, todo lo miserable y abyecto que puede contener una organización social dictatorial y burocrática"61; se pone en marcha contra los hipócritas.

crítico Franz Horn, en 1805, reunió estos escritos en un almanaque, en el que decía que "Fausto y Don Juan son las cumbres de la moderna mitología cristiana poética. Los dos mitos, a causa del universalismo de su carácter romántico, han obtenido acceso a todas las naciones", como se cita en la edición que Regula Rohland de Langbehn auspicia en Don Juan y Fausto, de Christian Dietrich Grabbe. También, entre los precursores -el Dios de la Creación, para los cristianos-, del personaje fáustico, se encuentra Simón Mago, figura temprana del gnosticismo y propulsor de la concepción por la que el Dios cristiano es, en realidad, un demiurgo.

58 Así lo recoge Friedrich W. Murnau en su Faust cinematográfico.

59 Algunos, como Elisabeth Butler, dicen que han encontrado una significación etimológica en Mefotofiles (enemigo de la luz), Mefaustofiles (enemigo de Fausto) o Mefiz-Tofel (destructor-mentiroso), como señala Naranjo Escobar, J., «La Acedia Mefistofélica», Mito. Revista cultural, 8 (2014), 14 de abril de 2014 (revista electrónica: ISSN 2340-7050).

60 Guelbenzu, J. M., «Prólogo», El maestro y Margarita, Barcelona, Random House Mondadori, 2010, p. 12.

61 Ibidem, p. 13. En este territorio, «de lo "miserable y abyecto"», encontramos la obra plástica de Tala Madani, en la que, según Juan Bosco Díaz-Urmeneta, "con una pintura sencilla pero exacta, la autora elige adentrarse en el difícil terreno de lo abyecto. Lo abyecto, según Julia Kristeva, es aquello de lo que hay que deshacerse para llegar a ser un yo. El principal problema que plantea es que eso que hay que alejar (sudor, heces, orina) es íntimamente nuestro. [...]. Madani cambia la perspectiva y muestra sobre todo la cercanía de lo abyecto. Constituye nuestro interior. [...]. Su trabajo es en parte una cura de humildad para una cultura, la nuestra, que no ha logrado aún discernir qué dosis de narcisismo nutren sus más excelsas creaciones". Puede verse en Bosco Díaz-Urmeneta, J., «Terreno de lo abyecto», Babelia, Madrid, El País, 31 de mayo de 2014, p. 16. Ahora, relaciónese, esto, con las organizaciones burocráticas y con los sistemas de dominación. Y, si fuésemos más allá -en ese terreno miserable y abyecto-, nos encontraríamos con las pinturas de Théodore Géricault, sobre los acontecimientos de la fragata francesa Medusa, descritos, también sonoramente, por ejemplo, en Oratorio volgare e militare, in due parti, Das Floß der Medusa (1968), de Hans Werner Henze; o con los detalles del naufragio del pequeño carguero inglés Mignonette, narrado por Schirach, F. von, «¿Tortura salvadora?», Babelia, Madrid, El País, 7 de diciembre de 2013, pp. 4-5 [Der Spiegel]; o con la brutal producción cinematográfica de Deodato, R., Holocausto caníbal, Barcelona, Manga Films, 2002 [Italia, Franco Palaggi, 1979] (DVD). Y para relacionar este «terreno» miserable y abyecto, con el centenario que se conmemoró en 2014 -del estallido de la Gran Guerra-, Harold Evans menciona el libro de Christopher Clark, Sonámbulos, en el que, como apunta Evans, se narra cómo 28 oficiales del ejército serbio, once años antes del asesinato del archiduque Francisco Fernando, en 28 de junio de 1914, en Sarajevo, asesinan con saña al rey Alejandro y a la reina Draga: "los acribillan a balazos, los acuchillan con una bayoneta, los muelen a hachazos y los destripan a medias, les mutilan los rostros hasta hacerlos irreconocibles y arrojan los restos sangrientos y medio desnudos por el balcón real a los jardines". Fue un prólogo fáustico de lo que vendría después: "Los participantes se veían impulsados a seguir caminando a lo largo de un declive escarpado, seguros de su propia brújula moral, pero impelidos, sin que ellos 
Es "un diablo al que le molesta extraordinariamente la estupidez." 62 Y Mefisto detesta a la sociedad, entre la que se encuentre en un instante determinado.

\section{El mito precede a la Historia}

Porque el mito es lo primero -lo primitivo (ur), lo primigenio-, después llega la Historia; en sus distintas vertientes: política, social, religiosa, artística, etc. Hicimos decir, a uno de nuestros personajes 63 -en una producción escénica de otra temporada-, que es el mito el que funda la Historia; no al revés. Así lo recoge el poeta Manuel Neila, en su Diálogo con Asklepios: "el mito fue abolido definitivamente por el pensamiento crítico e histórico del Siglo de las Luces. [...] Sin embargo, el precio que hubo de pagarse por el exterminio de los viejos mitos fue la aparición de otros nuevos; [...] el mito no puede ser desterrado, vencido por la histo-

lo supiesen, por una compleja interacción de culturas, patriotismo y paranoia profundamente arraigados, sedimentos de historia y memoria popular, ambición e intriga", es decir un todo fáustico. Y Christopher Clark, como si de Faustos mismos nos hablara, dice: "«sonámbulos, vigilantes pero incapaces de ver, poseídos por sus sueños pero ciegos a la realidad del horror que estaban a punto de traer al mundo»", porque, quizá, el horror no necesita ser traído, sino que, como aventuró George Gordon, habita en nosotros: el horror es la única realidad que sustenta nuestra existencia. Los textos citados, se encuentran en Evans, H., «Sonámbulos. Cómo Europa fue a la guerra en 1914», El Cultural, Madrid, El Mundo, 23 de mayo de 2014, p. 21. También, en Clark, Ch., Sonámbulos (traducción de Irene Cifuentes y Alejandro Pradera), Barcelona, Galaxia Gutenberg / Círculo de Lectores, 2014 [2012].

62 Guelbenzu 2010, op. cit. (nota 60), p. 13.

63 Asklepios de Megara, personaje médico denostado, "desterrado del tiempo", quizá por ser un permanente rival del cristianismo, y que está vinculado con el teatro de Epidauro. Puede consultarse Bonnefoy, Y., Diccionario de mitologías (traducción de Cristian Serna, Maite Solana y José Manuel Álvarez Flórez), Barcelona, Backlist / Planeta, 2010, pp. 187-190. En este sentido, podemos conectarlo con la «curación» que, para sí, pretende Fausto, insatisfecho con la ciencia y con la religión; incapaces, éstas, para solucionar sus problemas "existenciales". Una curación que, en primera instancia, encontrará en la figura de Mefisto, que le proporciona la posibilidad «curativa» por medio de un «donjuánico» atavío, representado en la conquista de Margarita; a su vez, en la recuperación goetheana de la juventud -"Afortunada juventud, que ve aquello que no existe", dice una mujer mayor en el film Novecento-. Además, una conversación interesante, hipotéticamente mantenida por Asklepios con un cronista actual, puede encontrarse en Neila, M., El silencio roto, Gijón, Llibros del pexe, 1998, pp. 7783. La palabra "mito", en castellano, entró, en la lengua hablada, bastante tarde: en el último tercio del siglo XIX, como indica García Gual, C., «Héroes y dioses», Babelia, Madrid, El País, 24 de noviembre de 2012, p. 4. Y, volviendo al propio mito -como fundador de la Historia-, podemos citar un texto de Ana María Leyra, en el que dice que "para Aristóteles el mito representa el contenido básico de la pieza trágica"; ¿tal vez, el contenido básico de nuestra existencia? Puede verse en Leyra 2006, op. cit. (nota 55), p. 135. Porque, como arguye Mijaíl Bulgákov a través de uno de sus personajes, "el fin de todo esto es trágico: el que hace muy poco se sabía con el poder en las manos, se encuentra de pronto inmóvil en una caja de madera; y los que le rodean, conscientes de su inutilidad, le queman en un horno". Puede verse en Bulgákov, M., El maestro y Margarita (traducción de Amaya Lacasa Sancha), edición de Debolsillo Contemporánea, Barcelona, Random House Mondadori, 2010 [1990], p. 31. 
ria, puesto que funda la historia"64; uno de esos mitos "nuevos" es el de Fausto. Esta afirmación, nos sitúa en un estadio que, siendo contundente, aporta una nueva visualidad, y otra concepción y comprensión del mundo; un mundo, el de la vieja Europa, que se construye a partir de los relatos míticos - de fabulación y de confabulación (sic) (de poder) - y que, casi sin ser consciente, reproduce, repite, consuma y perpetúa en los modelos en herencia -los que, por otra parte, no solemos cuestionar-65. Poner en científica tela de juicio, los valores y principios heredados, no es algo habitual, pero que podemos presumir como necesario, para madurar, para emanciparnos 66 del lastre-bagaje de esa herencia; para acogernos al librepensamiento, si se quiere. Napoleón decía que la Historia es una mentira que nadie cuestiona ${ }^{67}$. Si esto fuera así, estaríamos renunciando a la posibilidad de vivir otra vida en vida, tal y como propuso Anton Chéjov. Como dice Emilio Lledó, "el mito alumbra e inspira, pero es siempre un paso previo en el camino del conocimiento. Enseña libertad [...] si no cae en manos de sectas y fanáticos que corroen, desde la infancia, el cerebro de los que de alguna forma dominan, para hacer olvidar el camino más largo, más duro, más interminable, más hermoso del pensar. [...]. Abren camino, pero no son el camino que, con la educación, con la paideia que es cultura y no aprendizaje, hay que andar para ser ciudadano de una «polis» libre, de una política en la verdad [...]. En esa educación para la ciudadanía no cabe la indecencia, ni los mitos impuestos por los profesionales de la mentira."68

64 Neila 1998, op. cit. (nota 63), pp. 78-79.

65 Esta «imitación»-o «i-mita-acción»- del mito, que va trascendiendo-se (sic), encuentra justificación neurocientífica en los estudios que existen, por ejemplo, respecto al funcionamiento de las neuronas espejo. Sobre el caso, puede consultarse Gazzaniga, M. S., ¿Quién manda aquí? El libre albedrío y la ciencia del cerebro (traducción de Marta Pino Moreno), Barcelona, Paidós, 2012 [2011].

66 Una emancipación que, según Michel Onfray, llegará a través de una "descristianización radical de la sociedad". Puede verse en Onfray, M., Tratado de ateología (traducción de Luz Freire), Barcelona, Anagrama, 2006, solapa. Las razones de las resistencias, para poner «en barbecho»-cuando menoslos principios y valores heredados, pueden hallarse en un capítulo titulado «Por qué no queremos cambiar de opinión», de la referencia Punset, E., El viaje al poder de la mente, Barcelona, Destino, 2010, pp. 61-90. Y el físico Jorge Wagensberg aporta algunos aforismos sobre estas tradiciones que, todos, heredamos sin cuestionar: "La tradición nunca es suficiente, ella sola, para justificar absolutamente nada"; "Un país da el salto definitivo a la modernidad en el momento exacto en que cae en la cuenta de que adquirir nuevo conocimiento pesa más en su identidad que el conjunto de todas sus tradiciones"; "La tradición es el lastre del espíritu de los tiempos", que pueden encontrarse en Wagensberg, J., «La tradición en aforismos», Babelia, Madrid, El País, 19 de julio de 2014, p. 2.

67 El comentario, es recogido en un film de Caunes, A. de, Monsieur N (La última batalla), Francia / Reino Unido, Loma Nasha, 2002 [DVD: Laurenfilm SA, 2006], minuto 31, aproximadamente. Sobre un guión de Rene Manzor. (DVD)

${ }^{68}$ Lledó, E., «El amante de los mitos», Babelia, Madrid, El País, 24 de noviembre de 2012, p. 6. 


\section{Protagonismo de Mefistófeles}

Con su pacto de sangre, Fausto recupera el poder sobre sí mismo ${ }^{69}$ y sobre el mundo; el pacto, le libra de toda tutela. 70 Porque, como explica Antonio Damasio, "la simple presencia de imágenes organizadas que fluyen en una corriente mental produce una mente, pero si no se le añade algún proceso complementario, la mente se mantiene inconsciente. Y en esa mente inconsciente lo que se echa en falta es el sí mismo. Aquello que el cerebro precisa para hacerse consciente es [...] la subjetividad"71, siendo un rasgo, definitorio de la subjetividad, "el sentimiento que invade las imágenes de las que tenemos experiencia subjetiva."72 Así pues, parece que "el paso decisivo en la elaboración de la conciencia no es la formación de imágenes, $[\ldots]$ [sino] hacer las imágenes propias, [...] que correspondan a sus legítimos dueños"73. En dicho sentido, vamos «allanando el terreno» si logramos entender que Fausto es dueño de Mefisto.

Dos representantes de la unión entre escritura e imagen son Hildegard von Bingen y Alfonso X: monodia, organa y miniaturas, para la primera; cantigas y miniaturas, para el segundo. Digamos que el Diablo es, incluso y contra muchos pronósticos, el único personaje masculino, insustituible, de una obra escénica de Hildegard von Bingen, y ¡en pleno siglo XII! ${ }^{74}$ Si Hildegard von Bingen no hubie-

69 Sería oportuno especificar a qué sí mismo nos referimos, pues, como indica Antonio Damasio -en su investigación sobre la consciencia de existir-, podemos encontrar: un sí mismo como sujeto, un sí mismo como sujeto que conoce, y un sí mismo como objeto. Se trataría de definir a Fausto como "una mente capaz de saber que un organismo así, que vive y actúa, existe". Puede verse en Damasio, A., $Y$ el cerebro creó al hombre. ¿Cómo pudo el cerebro generar emociones, sentimientos, ideas y el yo? (traducción de Ferran Meler Orti), Barcelona, Destino, 2010, pp. 28-29. Por otra parte, podemos recordar la paradoja entre el yo real y el yo que inventamos, referida por Jorge Luis Borges en su obra $E l$ Aleph. Recordemos, también, que "conocerse a sí mismo" es el anhelo de Edipo, como puede verse en García Gual, C., «La pervivencia de la mitología clásica en nuestra cultura», Música y mito, 4 (2005), vol. I, Madrid, OCNE, 2005, p. 12.

70 Este análisis lo tiene en cuenta Onfray 2006, op. cit. (nota 66), p. 112. También, puede ser oportuno, en lo que se refiere a la relación «estética-poder», consultar la incidencia que ha tenido el Arte Musical en que se produzca "una inversión de la estética que permita al espectador tomar conciencia de su propia alienación”, como sugiere, a partir de la obra de Luigi Nono, Chouvel, J.-M., «Los monstruos fríos. Imagen y música en tiempos del capitalismo avanzado» (traducción de Heike Freire), Escritura e imagen, 5 (2009), pp. 39-48.

71 Damasio 2010, op. cit. (nota 69), pp. 29-30.

72 Ibidem, p. 30.

73 Ibidem

74 Nos referimos a Ordo Virtutum. Puede verse en Bingen, H. von, Ordo Virtutum, The Ritual of the virtues (directores: Michael Fields y Evelyn Tubb); Ansy Boothroyd, John Hancorn, Vox Animae, Mayfield Chamber Opera Chorus, Michael Fields (arpa), Piers Adams (flauta de pico), Steven Devine (percusión), UK, BBC Opus arte, 2003 [filmación, de Ordo Virtutum, en 1997] (DVD). También, encontramos la referencia demoníaca en Sed diabolus in inuidia sua, un canto monódico recogido en Bingen, H. von, Symphonia armonice celestium reuelationum (director: Stevie Wishart). Vivien Ellis, Jocelyn West, Sara Stowe (Oxford Girls Choir), Madrid, Glossa, 2001. (CD) 
se sido quien fue, probablemente, habría sido acusada, como mujer ${ }^{75}$ que era, de brujería y maleficio; no habría llegado a cumplir 81 años de existencia, pero tenía ese poder, que, además, le permitió asesorar a papas y señores de su tiempo76; ¿quizá, eso, le salvó la vida? Aproximadamente, cien años después, Alfonso X -el rey de Castilla llamado "el Sabio", pero que, también, pudo haber trascendido como «el misógino»77- «adopta» un personaje femenino -la Virgen cristiana- como modelo de virtud, frente as outras; una «mujer» que "nos quita el miedo al demonio"78, "en cujo poder outras donas van / mete-los seus, e coita e afan / lles fazen soffrer, atal costum' an; / poren non é leal o seu amor. ${ }^{79} \mathrm{El}$ rey Alfonso establecerá, en el siglo XIII, una comparación: entre el poder que ejercen las mujeres sobre los hombres y el que parece proceder del mismo demonio. Así las cosas, la misoginia estaría «servida». Por tanto, finalmente, ¿quién detenta el poder? ¿Quién es el creador de ese "demonio"? Como hemos adelantado, Fausto es dueño de Mefisto.

Sabemos que es el miedo el que erige las religiones 80 , y el que perpetúa los sistemas de dominación, de poder, que pervierten al individuo; para que, este último,

75 “Por qué sólo se quema a mujeres, y no a los hombres?”, pregunta la madre de Margarita, a Mauricius Müller (Mefistófeles), en el Fausto de Alexander Sokurov. Puede verse en Sokurov, A., Fausto, Rusia, 2011 [estrenada en 2 de marzo de 2012]. (DVD)

76 Puede consultarse Damme, F. van (prod.), Hildegard von Bingen, In Portrait (Hildegard: Patricia Routledge); A Real Mystic (Professor Matthew Fox y Mary Grabowsky); A Source of Inspiration (The Washington National Cathedral); Illuminations (Professor Matthew Fox), UK, BBC Opus arte, 2003 (DVD). También, Cirlot, V., Vida y visiones de Hildegard von Bingen (Biblioteca medieval), Madrid, Siruela, 2001. Igualmente, el film de Trotta, M. von, Vision. Aus dem leben der Hildegard von Bingen, Alemania/Francia, Karma (dist.), 2010 [2009]. (DVD y CINE)

77 El musicólogo Pepe Rey, así, lo estima. Puede verse en Rey, P., «Un cancionero de ilusiones y desencantos», Las cantigas de Alfonso el Sabio, Grupo SEMA (director: Pepe Rey), Madrid, Discos Oblicuos, 2000, p. 6 (CD). Y Tomás de Aquino pensaba -como nos recuerda José Antonio Marinaque "«el varón es más perfecto [que la mujer] por su razón y más fuerte en virtud» (Contra gentes, III, 123)". Puede leerse la cita en Marina, J. A., La inteligencia fracasada, Barcelona, Anagrama, 2008, p. 42. También, Marina menciona claros fracasos de la inteligencia: el prejuicio, la superstición y el dogmatismo, "y una peligrosa condensación de todos, que es el fanatismo". José Ortega y Gasset "distinguió entre ideas y creencias. Las ideas se tienen, las creencias se son". Puede leerse en Marina (2008) op. cit. (nota 77), p. 34 y 44, respectivamente.

78 "Que perdamos do demo pavor". Puede leerse -y oírse- en la cantiga 130, "Esta é de loor de Santa Maria", en Grupo SEMA, Las cantigas de Alfonso el Sabio (director: Pepe Rey), Madrid, Discos Oblicuos, 2000, p. 41. (CD)

79 "En cuyo poder las otras mujeres ponen a sus enamorados y les hacen sufrir cuitas y afanes, por lo que su amor no es leal". Es una transcripción, de Pepe Rey, de la cantiga 130 (Quen entender quiser), recogida en SEMA 2000, op. cit. (nota 78), p. 42 (CD). En esta referencia, encontramos el asunto del sí mismo, cuando Pepe Rey, al referirse a la cantiga 200, de Alfonso X, dice que "el autor parece mirar más hacia sí mismo que hacia su dama", que es la virgen María. Puede verse en p. 11. ¿Sería, la virgen María, la excusa, el objeto -como herramienta- y el medio fáustico para encontrarse consigo mismo? ¿Como Margarita sería un medio para el si mismo de Fausto?

80 Así lo expone José Antonio Marina en su Radiografía del miedo. También, encontramos menciones a toda una elaboración y construcción a partir del miedo -desde las posturas de Ludwig Feuerbachen Onfray 2006, op. cit. (nota 66), p. 49 y otras. En cuanto al «uso» de recursos amedrentantes de 
anhele otra vida inexistente -normalmente, después de la vida regalada ${ }^{81}$. Como dice Fernando Aramburu, los hombres "exigen libertad y derechos, pero dadles una cadena de oro y ellos mismos se atarán a la argolla de la pared." 82 Nos parece que el «miedo divino» es el «primer» (ur) miedo adulto, que ejerce, contundentemente, su poder; un poder de «lo ficticio» sobre «lo refutable». Michel Onfray dice: "Dios no está muerto [...], porque no es mortal. Las ficciones no mueren, las ilusiones tampoco; un cuento para niños no se puede refutar. Ni el hipogrifo ni el centauro están sometidos a la ley de los mamíferos. Un pavo real, un caballo, sí; un animal del bestiario mitológico, no. Ahora bien, Dios proviene del bestiario mitológico." 83

Tal vez, la búsqueda de un personaje «malvado», portador de un gran catálogo de fechorías imaginarias e imaginadas, nos permita ahogar y «lavar» nuestra mala conciencia. Algunos, entendemos que el único ser bondadoso sólo puede ser un Mefisto cualquiera, que cargue con la culpa de toda la maldad humana: sería como un Jesucristo -si hubiese existido ${ }^{84}$, que asumiese el pecado original de los cristianos; es el otro yo -alter ego- de Fausto. Por este último motivo, nuestro Mefistófeles -nuestro Lucifer, nuestro Valand, nuestro Asmodeo, nuestro Asasel, nuestro Mauricius Müller- es el único superviviente de la farsa/vida. También, por ello, todos nuestros actores asumen, en algún momento, y bajo su prosopon, el papel «protagonista»-haciendo «de las suyas»-, que es, sin duda, el rol del querido Belcebú. Fausto es aquel que llega a desear, desde un principio (ur), lo que es perecedero, a costa de quien sea, porque está cansado y decepcionado de la ciencia y de la religión; cansado de vivir entregado al conocimiento. Ni ciencia ni religión hay que puedan ofrecer soluciones para frenar la peste. Fausto inicia una búsqueda que no le aporta respuestas, y, por ello, quiere el refugio del suicida. Por esto, la versión de Goethe ${ }^{85}$, algunos, la han visto como una nueva aportación al mito, al con-

poder, que inoculan miedo en el sujeto, éstos suelen ser vistos como "emisarios del inframundo, que irrumpían en el nuestro gracias a la fuerza invisible del magnetismo animal", como dice Montiel, L., «Mensajes del inframundo. Las kleksografías de Justinus Kerner», Escritura e imagen, 1 (2005), p. 145 .

81 "La muerte, está tan segura de su victoria, que nos deja una vida de ventaja", podía leerse en una pintada en la estatua del cabo Noval, en la plaza de Oriente, en Madrid.

82 Aramburu, F., «Pequeña magnitud», Babelia, Madrid, El País, 21 de septiembre de 2013, p. 2.

83 Onfray 2006, op. cit. (nota 66), p. 32.

84 Nos lo recuerda Berlioz, un personaje de Bulgákov, que nos dice que "no existe ninguna religión oriental en la que no haya, como regla general, una virgen inmaculada que dé un dios al mundo. Y los cristianos, sin inventar nada nuevo, crearon a Cristo, que en realidad nunca existió. Esto es lo que hay que dejar bien claro...". Tampoco Josefo Flavio hizo "mención alguna de la existencia de Jesús. [...] [Ese] punto del capítulo 44 del libro 15 de los famosos Anales de Tácito, donde se habla de la ejecución de Cristo, no es más que una añadidura posterior y falsa. [...] [La] clave está en que antes de Cristo habían nacido toda una serie de hijos de Dios; como el Adonis fenicio, el Attis de Frigia o el Mitra persa. En conclusión, ni nacieron ni existieron ninguno de ellos. Y Cristo, por supuesto, tampoco". Puede verse en Bulgákov 2010, op. cit. (nota 63), pp. 26-27.

85 Podemos decir que Wolfgang Goethe incorporó, en la obra de toda una vida -que fue su Fausto-, 
cebir la maldad de Fausto como un decaimiento, con tristeza y angustia, pero, sobre todo, con pereza y flojera; es decir con acedia mefistofélica. ${ }^{6}$ En este momento, Mefistófeles se convierte en protagonista. No es Mefisto quien tiende una trampa, y pone en un aprieto, a Fausto, sino que es el mismo Fausto el que recurre a Mefisto, porque es el único que le ofrece el carpe diem absoluto, representado por el «dejarse llevar» o dejarse ir: una «flojedad» existencial. Para aquel que piensa -y es acertado, así, pensarlo- que, en Venus, el día es más largo que un año, la vida es una "experiencia «sin salida», o «sin otra salida» que la que la muerte puede proporcionar."87 Pero la verdadera trampa, como decía Gabriel García Márquez, es la muerte. En el marco de este paraje desolado y yermo; gélido -como la imagen que marca el incipit del film Remando al viento ${ }^{88}$-, si establecemos un vínculo con el ansia de poder, es oportuno citar una reflexión que Mijaíl Bulgákov pone en palabras, para nuestro Mefisto, y que dice que, "para dirigir algo [-un país, un Estado o cualquier otra estupidez-, incluso sus propias vidas,] es preciso contar con un futuro más o menos previsible; y díganme: ¿cómo podría estar este gobierno en manos del hombre que no solo es incapaz de elaborar un plan para un plazo tan irrisorio como mil años, sino que ni siquiera está seguro de su propio día de mañana? [...] [Es víctima de] un sarcoma pulmonar [...], iy se le acabó la capacidad de gobierno! Todo lo que no sea su propia vida, dejará de interesarle."89

George Gordon, alias lord Byron, nos condujo por el recoleto laberinto de lo horrísono, como único sustento de nuestra existencia: "Tuve un sueño, que no fue

referencias claras a sus vivencias, sobre todo en lo que se refiere al «ajusticiamiento», vilipendio y condena de Margarita. Goethe conoció, de primera mano, las acusaciones de asesinato, por infanticidio, contra mujeres de su tiempo (Sussana Margaretha Brandt, Catharina Maria Flindt). ¿Fue, éste, el origen del personaje de Margarita? ¿Puede verse su Fausto, también, como un conjunto de descargas psicológicas, como un «lavado» de su propia conciencia, por cuanto pudiera haber hecho y no hizo, al no intentar que miembros de su familia, que decidieron las ejecuciones de la pena capital, lo evitaran? ¿Se sintió, en cierta medida, culpable? Así, parece exponerlo Sala Rose 2006, op. cit. (nota 56), pp. 49-51. ¿Se disculpa a Fausto, "cargando la culpa sobre Mefisto"?, como argumenta Schöne, A., «Notas al Fausto de Goethe» (traducción de Miguel Sáenz), Fausto, 5 (2006), Madrid, OCNE, 2006, p. 38. 86 "Lo que Mefistófeles ofrece no es más que acedia, un lecho de pereza en el que el ser humano aspira a tenderse a fin de gozar plácidamente de todo aquello que ha conquistado mediante el derroche de su energía vital", tal y como dice Naranjo 2014, op. cit. (nota 59).

87 Es un texto de Leyra 2006, op. cit. (nota 55), p. 69. También, es un aserto que encontramos en Goethe, cuando viene a decirnos, en su Fausto, que sólo queda, al encontrarse ante obstáculos invencibles, el contentamiento en la desesperación; el reposo, sólo, en la muerte. Y, en esta catábasis, estrechamente vinculada con el deseo de poder, Leyra menciona a Pier Paolo Pasolini, en cuyo decir pone que "la vida es una película en la que la muerte lleva a cabo el montaje: una muerte heroica puede borrar un comportamiento miserable, y, por el contrario, una muerte vil puede hacer de alguien, intachable en el pasado, un ser abyecto." Esto, puede leerse en la p. 180 de la referencia citada y expuesta en esta nota.

88 Suárez, G., Remando al viento, Madrid / Noruega, Ditirambo Films, SA / Iberoamericana de TV / Viking Films, 1988 [Warner, 2005 (DVD)]. (CINE)

89 Bulgákov 2010, op. cit. (nota 63), p. 31. Las partes de texto, entre corchetes, son añadidos nuestros; del libreto para la dramaturgia de nuestro Urfausto. 
un sueño. El sol se había extinguido; las estrellas vagaban a oscuras en el espacio eterno, sin luz y sin rumbo, y la helada Tierra oscilaba ciega y negra en el cielo sin luna. Llegó el alba y pasó; y llegó de nuevo sin traer el día."90

Mefistófeles es un verdadero presentador, que sólo entiende que es el presente aquello que existe. Como el deseo parece que es la perdición de los seres humanos, traeremos a colación unas palabras -que no diremos a quién se atribuyen, aunque lo sugeriremos después-, y con las que aprovechamos para invitarles a investigar quién pudo ser su autor: "En aquél que depende [de otros], hay vacilación. En aquél que es independiente, no hay vacilación. Donde no hay vacilación, hay sosiego. Donde hay sosiego, no hay apasionado deleite. Donde no hay apasionado deleite, no hay ir y venir [...], no hay caída de un estado a otro, no hay «aquí» ni «más allá» ni «aquí-y-allá». Ése, es el fin del infortunio."

\section{La asunción de un conflicto: Fausto hoy}

Como Fausto no se atreve, explícitamente, a abandonar la existencia, inventa a Mefistófeles; por eso, le invoca; le llama, para que Mefisto se tome, por él, la cicuta ${ }^{91}$. Probablemente, antes desearía consumar, y «eternamente», sus deseos. En este

90 Es un texto perteneciente a Darkness, con el que, además, da comienzo el film Remando al viento, de Gonzalo Suárez. Puede verse en Suárez, G., Remando al viento (guión cinematográfico), Madrid, Plot, 1988, p. 7. Otra traducción, puede encontrarse en Pérez, Á. (ed.), La noche de los monstruos. Textos de Mary W. Shelley, Lord Byron y John William Polidori (traducciones de Mercedes Rosúa y Ángela Pérez), Barcelona, Edhasa, 2012, p. 11.

91 Este hecho, es relatado, irónica y muy cómicamente, por Sokurov 2011, op. cit. (nota 75) (DVD). En el fondo, puede ser que Fausto esté obsesionado con la inmortalidad, como Walt Disney en los años cuarentas del siglo XX, quien era, "por definición, un personaje fáustico"; dispuesto a "cumplir sus sueños a costa de su alma... y de la de los demás", como señala Palacios, J., «El americano perfecto. Tras la pista de Walt Disney», El Cultural, Madrid, El Mundo, 8 de febrero de 2013, p. 22, en un artículo-reseña sobre la novela de Peter Stephan Jungk. También, mencionaremos la ópera de Philip Glass: The Perfect American, pues en ella se vincula este afán de inmortalidad con el trasunto del poder, y a través de las sugerencias de imágenes que la música misma estimula. Además, pueden consultarse los artículos recogidos en el programa de mano, ad hoc, de Teatro Real de Madrid (ed.), The Perfect American, Madrid, Teatro Real, 2013. Pero si atendemos a lo que dice Antonio Escohotado, en cuanto a que "para que se solucione la muerte, debe frenarse la fertilidad. Una humanidad inmortal sería una humanidad sin descendencia. Y el universo conspira porque no hemos logrado aún la suficiente perfección como para que valga la pena conservarnos. Me temo que tendremos que seguir muriéndonos hasta que seamos más perfectos", entonces vemos que Fausto -al menos, en el caso de la obra de Goethe- no puede ser inmortal, pues, al «poseer» a Margarita, tendrá, con ella, un hijo -que perece-; después, otro con Helena de Troya: Euforión. La reflexión de Antonio Escohotado se encuentra en Arjona, D., "Antonio Escohotado: "La inteligencia siempre vence a la terca voluntad"», El Cultural, Madrid, El Mundo, 4 de octubre de 2013, p. 11. Carl Gustav Jung “descubría el poder fáustico que se agazapa en la naturaleza humana, tan deudora del bien como del mal", como indica Moreno Claros, L. F., «Las raíces del alma», Babelia, Madrid, El País, 8 de marzo de 2014, p. 13, en una rese- 
punto, recordamos al protagonista de El fuego fatuo -film de Louis Malle-92, que, antes de quitarse la vida, desea volver a estar con sus amantes. Alain Leroy, el protagonista, se dice a sí: "Me odio"; se siente culpable y vacío. ${ }^{93}$ ¿Es, este caso, un ejemplo de contemporaneidad del mito, en el año 1963? Mefisto, a Fausto, le sirve para justificar sus humanas tropelías y para consumar sus deseos, en otro tiempo reprimidos, que la ciencia no supo satisfacer del todo -ni la ciencia ni la religión, como hemos dicho; ¿quizá, el arte?-. Se mira en el espejo, pero no lo soporta ${ }^{94}$; no se gusta. William Shakespeare nos recordó que las cosas de este mundo se anhelan con más pasión que se gozan, como si de un donjuanismo patológico se tratase, $\mathrm{y}$, sobre ello, Mefisto dirá: "Mi buen Doctor, ¿deseas saber qué es la dicha? La dicha es la modestia con la que el gusano no intenta avanzar más de lo que sus fuerzas le permiten... Dicha es, como lo hace Don Juan (de quien mucho puedes aprender), gozar continuamente y no enfermarse del estómago... Desgracia es que tu espíritu sea muy débil para digerir comidas terrenales y sanas, y por eso picotea quimeras..."95. En este caso, recordamos un deseo del cineasta Bernardo Bertolucci, cuando explicaba las motivaciones para la génesis de El último tango en París: "He deseado siempre encontrar a una mujer en un apartamento desierto, que no se sabe a quién pertenece, y hacer el amor con ella sin saber quién es, y repetir este encuentro hasta el infinito, siempre sin saber nada. Último tango es el desarrollo de esta obsesión muy personal (y quizás banal)"96. ¿Estábamos, en el año 1972, ante un ejemplo fáustico contemporáneo; como puede serlo el deseo de «pasar a otra vida» que no reprima el disfrute de lo que «tenemos, ahora, entre manos»?

ña sobre la edición de la obra completa de Carl Gustav Jung. Sobre Jung, estamos recordando el documental de Shang, S.: Carl Gustav Jung. Edición restaurada de la entrevista realizada por el Dr. Richard I. Evans al Dr. Carl Gustav Jung, en agosto de 1957. Barcelona: Kaplan, 2007 (CINE). También, el film de Cronenberg, D., Un método peligroso, EEUU, Universal, 2011. (DVD)

92 Malle, L., El fuego fatuo (Le feu follet), Madrid, Avalon, 2010 [France, Nouvelles Éditions de Films, 1963 (CINE)]. (DVD)

93 Como indica Alberto Quintanilla, Alain es "incapaz de amar de verdad y se da cuenta. No está seguro de si alguna vez lo logró pero ahora ya es imposible y solo percibe vacío en su interior. [El] ansia de culpabilidad se multiplica. No sabe amar realmente ni a su mujer ni a su amante. Ni a él mismo". Hasta aquí, podríamos pensar, en parte, en la actualidad del mito. Puede verse en Quintanilla, A., «Análisis de "El fuego fatuo". El último viaje de un hombre llamado Alain Leroy», El fuego fatuo, Madrid, Avalon, 2010 [Francia: 1963], p. 5 [libreto]. (DVD)

${ }^{94}$ Lo mismo le sucede al personaje Harry Angel, que interpretaba Mickey Rourke en el film de Parker, A., El corazón del Ángel (Angel Heart), USA, Universal, 2001 [Canal +, 1987]. (DVD)

95 Este texto, de Grabbe, se lo hicimos decir a Mefisto, en una conversación con Fausto, en nuestra producción dramática. La conexión entre Fausto y Don Juan es clara en la obra de Grabbe, Ch. D., Don Juan y Fausto. Edición de Regula Rohland de Langbehn (traducción de Marcelo G. Burello y Regula Rohland de Langbehn), Madrid, Cátedra, 2007, p. 124.

96 Bertolucci, B., Bertolucci por Bertolucci. Entrevistas con Enzo Ungari y Donald Ranvaud, Madrid, Plot, 1987 [1982 y 1987], p. 90. 
Por otra parte, el conflicto, del cristianismo primitivo y de la civilización antigua ${ }^{97}$, nos arrostra con «ese» cuestionar nuestros valores y principios heredados, porque tenemos derecho -casi, obligación- de emanciparnos. Y es que nos parece que, el mito fáustico, acoge este conflicto como mítico ${ }^{98}$; nada más y nada menos que, también, como mito, y, con él, todos los mitos derivados de nuestra tradición helenística, griega; cristianos incluidos, por supuesto. Por eso, conviven y comparten, un mismo espacio, las mitologías griega y cristiana. Al final, una vez disueltas las controversias históricas, políticas y religiosas, sólo queda lo que queda: el mito, como sostén de la Historia. Una prueba posible de este «sostén» histórico es que, como dice Scott Atran, "Si los valores sagrados no son racionales, ¿por qué nos adherimos a ellos? Cuanto más absurdos parecen, más capaz es el hombre de sacrificarse por ellos. Los valores sagrados siempre son absurdos. Si fueran proposiciones lógicas, podríamos falsarlos, argumentarlos. Pero, si su carácter es trascendental, exterior a la razón, se tornan indestructibles." 99 La única posibilidad, para la desaparición de Dios, depende de la extinción 100 de sus creyentes. Cuando Dios se quede sin creyentes que lo mantengan vivo, dejará de existir. Cuando los creyentes dejen de creer, porque hayan desaparecido, su dios desaparecerá con ellos; dejará de haber «sostén», dejará de haber mito, por no tener lugar. Entonces, sí habremos «trascendido»: del ur-topos al u-topos.

97 Rougier, L., El conflicto del cristianismo primitivo y de la civilización antigua (traducción de Joaquín Bochaca), Barcelona, Nuevo Arte Thor, 1989. También, es muy oportuna la consulta de la compilación, de investigaciones sobre el asunto, hecha por Piñero, A. (ed.), Biblia y helenismo. El pensamiento griego y la formación del cristianismo, Córdoba, El Almendro, 2006. Llama nuestra atención, especialmente, lo que se trata en pp. 129-188, respecto del contacto del judaísmo con el helenismo, y sobre la traducción griega de la Biblia; en pp. 235-260, en cuanto a la consideración de Jesús como un predicador cínico, y sobre los datos aportados respecto a la fuente del documento Q; también, las pp. 419-470, para entender ese encuentro entre judaísmo y helenismo, y la composición del IV Evangelio.

98 Mítico como acepción de «confabulado». Así procede, si atendemos a la descripción de Leyra 2006, op. cit. (nota 55), p. 135. Sin embargo, Yves Bonnefoy explica que el "hecho de que todavía no exista un acuerdo completo entre los investigadores a propósito de su posible definición poco importa [...]. El lector no hallará [...] una definición del mito que sirva de ley”. A lo que sí se acoge Bonnefoy es a "los mitos entendidos como sistemas de comunicación". Se trataría, por tanto, de un conflicto que nos es «comunicado», transmitido como herencia «confabulada». Puede verse en Bonnefoy 2010, op. cit. (nota 63), p. X. Y Carlos García Gual indica que "el término griego mythos significa no sólo «relato tradicional», sino también «argumento» de una obra teatral en la Poética de Aristóteles, que, no por casualidad, utiliza repetidamente la palabra en ambos sentidos". Puede verse en García Gual 2005, op. cit. (nota 69), p. 12.

99 Puede verse en una entrevista de Giménez Barbat, M. T., «Scott Atran: "Todos los políticos son esclavos de intelectuales muertos"», El Cultural, Madrid, El Mundo, 3 de enero de 2014, pp. 8-10.

100 Del mismo modo que Helena de Troya, en la obra de Miguel del Arco, dice: "«Tal vez sea esa la única solución para que yo consiga el olvido: vuestra extinción»». Puede verse en Arco, M. del, «Juicio a una zorra», Primer acto. Cuadernos de investigación teatral, $\mathrm{n}^{\mathrm{o}} 342$ (2012), Madrid, Primer acto, enero-julio de 2012, p. 104. 
El fasto es ese carpe diem ${ }^{101}$-también fáustico- que nos mantiene en el hecho festivo, que es lo primigenio, pues es el deseo de exprimir la efímera existencia, antes de sucumbir: la primera -y última- fiesta (urfasto). Esta primera fiesta, este primer fasto, es la vida misma, y el fasto de vivirla -lo que nos parece más importante e ineludible, aunque sólo sea para conseguir ser conscientes ${ }^{102}$ de nuestro precario devenir-. Dirá nuestro Mauricius Müller -el «prestamista»- a un cura: “¿Qué es un día fasto si no se tiene fausto?"103.

Nos parece que es Madrid el único lugar, en Europa, que, quizá aún, no ha renunciado, del todo, a su tradición fáustica: ¿tal vez, porque erigió, en su día, una escultura dedicada al ángel caído? ${ }^{104}$ A pesar de que el personaje mitológico cris-

101 Con toda su evidencia, estamos pensando en el poema XI de Quinto Horacio Flaco, recogido en su libro primero. Puede leerse en Horace, Odes et épodes. Tome I (texte établi et traduit par F. Villeneuve), Association Guillaume Budé, Paris, Société d'édition Les Belles lettres, 1976, p. 20.

102 Volvemos a acordarnos de la obra de Damasio 2010, op. cit. (nota 69), en la que analiza qué es la con $($ s)ciencia.

103 Así lo recogen Alexander Sokurov y Marina Koreneva en el film Fausto. Puede verse en Sokurov 2011, op. cit. (nota 75). (DVD)

104 Como muchos sabrán, nos referimos a la estatua que se encuentra en el Parque del Retiro. Al parecer, existen, en otras dos ciudades americanas, sendas representaciones escultóricas del ángel caído. La de Madrid, «casualmente», está a 666 metros de altitud sobre el nivel del mar. De ello, según dicen, se dieron cuenta después de haber sido erigida la estatua. La evocación del hecho satánico, y la vocación por éste, se encuentran, también, muy extendidos en el ámbito de la música popular rock. Música rock y satanismo mantienen un vínculo del que han dado cuenta diversos estudios, sobre todo en Méjico. Esta manifestación, nos permite citar algunos ejemplos que ilustrarían la devoción por los máximos representantes contemporáneos, del satanismo, en el siglo XX: Aleister Crowley y Anton Lavey. Las músicas populares, de grupos como The Eagles -con su hotel de los hornos calientes (Hotel California), en el que se celebraban las misas satánicas a las que acudían representantes culturales populares-, como The Beatles -con su provocación, refiriéndose a Jesucristo, a través de una invocación satánica: Turn me on, dead man, recogida por el ingeniero Alan Parson, como grabación retrógrada, en las bobinas del master del tema titulado "Revolution 9", del White Album-, como Alice Cooper -nombre, al parecer, de una bruja del siglo XIX, cuyo espíritu se manifestó, en una invocación, a Vincent Fournier y que, éste, adoptó como seudónimo-, como King Diamond-que realizaba «celebraciones» satánicas en "conciertos", en los que descuartizaba animales, y de los que bebía su sangre-, como Kiss -cuyas siglas se refieren a los caballeros al servicio de Satanás (Knights In Satan Service), siendo además, Gene Simmons, uno de los miembros del grupo que, por cierto, es defensor de la creación y producción de Hugh Hefner (Playboy), aunque, esto, nada tenga que ver, según sepamos, con «lo satánico»-, como los australianos $A C D C$-con siglas que, aunque se han defendido como "corriente alterna, corriente continua", parecen indicar "Anti Cristo, Muera Cristo"-, como los españoles Ilegales -que, en las esquinas superiores de las portadas de las carpetas de sus discos, incorporan las imágenes de dos personajes de las mitologías judía, cristiana o/y musulmana: el ángel Lucifer y el ángel Gabriel, considerándose, ellos mismos, en medio, o sea "ilegales"-, etc. No obstante lo expuesto, podemos entender que, muchos casos, sean, sólo, reclamos publicitarios, en los que las imágenes, como elemento prohibido de seducción colectiva, permitan acercarse al territorio fáustico del ser humano: el objeto prohibido como objeto más deseado. Para profundizar sobre estas cuestiones, y para quien pueda tener interés, cabría la consulta de la revista Hit Parader, de febrero de 1987. Y, relacionado con lo anterior, casi en sentido opuesto, y tangencialmente -referido al carpe diem-, encon- 
tiano, de la luz (Lucifer), haya sido mostrado «cayendo», ese «caer», también puede representar la renuncia a una vida fáustica, con el sentido de vida fástica. Nuestro Mefisto no «cae», es el superviviente del relato: cuando no quede nada, permanecerá la posibilidad humana de sacar el mayor partido a la efímera existencia, que nos es única; completamente caduca; querámoslo, o no; aceptémoslo, o no. 105 Por tanto, muere el ego y sobrevive el alter ego. Quizá, en parte, la supervivencia del alter ego se deba a que "los hombres mueren y no son felices", como decía Calígula, en la obra de Albert Camus. 106

Al final, esta expresión dramática, que hemos creado, trata de dos pasiones humanas, combinadas y claras: la muerte y el amor; el bien y el mal. El amor-sexo sirve para perpetuar el gozo de la vida, el fasto que se nos presenta como una «ventaja» frente a la auténtica vencedora de la Historia: la muerte; la desaparición, la extinción del sujeto y de sus mitos con él. Como explica Francisco Calvo Serraller -al referirse a una obra de Junichirô Tanizaki107-, "el sexo humano suele expresar más de lo que aparenta, como el erosivo paso del tiempo, la ansiedad ante el atisbo de la muerte y la indeclinable conciencia de la soledad"108. La mezcolanza de sexo y muerte, en uno, son muy bien interpretados por la tradición del jazz-blues -erotismo y endecha-, a los que recurrimos en esta propuesta escénica de la que hemos partido. No siendo la satisfacción sexual el centro del mito acogido -sino el tema

tramos algunos ejemplos, como el del grupo Queen, que nos dice, en uno de los títulos de sus canciones: Another One Bites the Dust, frente a lo que podríamos ofrecer lo que le dice Mefisto a Fausto: “comerá polvo, y lo comerá con ganas", en el film de Sokurov 2011, op. cit. (nota 75). (DVD)

105 Los estudiosos, de Teología, saben que las creencias necesitan de creyentes, que mantengan vivos a los dioses. Un dios, sin gentes que crean en éste, sin clientes, muere, se extingue, sucumbe -aunque parezca lo contrario, como sucede con el asunto de la relación Mito-Historia-. Al revés de cuanto nos contaron: sólo los creyentes pueden mantener vivo a su dios, por miedo ante el hecho irrevocable del morir. Esta idea es, también, esbozada por Onfray 2006, op. cit. (nota 66), p. 33.

106 En cuanto al alter ego, para Gonzalo Torrente Ballester, "todos los casos de desdoblamiento de la personalidad literaria son siempre de hombres, no mujeres; los casos [...] de mujeres dúplices son muy elementales: Belle de jour... Yo los encuentro un poco artificiales, [...] todo eso son construcciones literarias. En la realidad, en el mundo real, ni siquiera las mujeres más cultas, más experimentadas, pierden esa unidad. Y esa, sobre todo, relación con la realidad. [...]. Las mujeres están más integradas en el cosmos que los hombres", como puede leerse en Castaño, F., Retrato de Gonzalo Torrente Ballester, Barcelona, Galaxia Gutenberg / Círculo de Lectores, 1996, p. 79. Recordamos, ahora, la Belle de jour interpretada por Catherine Deneuve, en 1967, en el film homónimo de Luis Buñuel. Un ejemplo de "Belle de jour para nuevos tiempos" -como dice Martínez, L., «El sexo y el miedo», El Cultural, Madrid, El Mundo, 7 de marzo de 2014, p. 48- es la actualización que, de este mito femenino, lleva a cabo François Ozon en su film Joven y bonita (Francia, 2013). La otra referencia dada, en esta nota, es Camus, A., Caligula, Madrid, Alianza, 1984 [Gallimard, 1947], p. 18; la obra fue estrenada, en París, en 1945.

107 La llave. Nuestra referencia es Tanizaki, J., La chiave (prefazione di Geno Pampaloni; noticia biobibliografica di Adriana Boscaro; traduzione di Satoko Toguchi), Milano, RCS Libri \& Grandi Opere, 1995 [Japan: Chuokoron-Sha, 1956].

108 Calvo Serraller, F., «Llave», Babelia, Madrid, El País, 31 de mayo de 2014, p. 16. 
del poder109-, sí puede convertirse, no obstante, en una nueva trampa; una trampa «en primer plano», que vuelve a hacerse actual, a través del consumo «internáutico», por ejemplo. 110 Como piensa Fernando Aramburu, "se llama red porque nos tiene a todos atrapados"111; una red como la que teje la rueca de Las hilanderas, de Velázquez; una rueca como el insistente y obstinado ventilador de El corazón del ángel, de Alan Parker; una red que ha atrapado a Tristán e Isolda, en la imagen que Helmut Ebnet utilizó para presentar una grabación de la ópera de Richard Wagner. 112

Hemos pretendido salvaguardar una idea primigenia: que Margarita tuviese poco más de catorce años de edad, y Fausto cuarenta y cinco113. Pensamos que este aspecto, aparte de intentar ajustarse a algunos modelos literarios precedentes, nos permitía producir un contraste de una gran contundencia expresiva y dramática,

109 Siendo, el poder, un asunto central en el mito fáustico, nos parece relevante la consulta, aunque fuese leve, de varias monografías que, desde distintos enfoques «occidentales» con sesgo, pueden dotar de actualidad perseverante al mito, y que sugerimos: Loperena, J. M., El abuso del poder. Crónica de sacadineros, politicones y otros fantoches de lo inmoral, Barcelona, Octaedro, 2013; Mintzberg, H., «Poder», La estructuración de las organizaciones (traducción de Deborah Bonner y Javier Nieto), Barcelona, Ariel, 1988 [Prentice-Hall Inc., Englewood Cliffs, 1979], pp. 330-340; Schueller, G. K., El politburó (traducción de E. Borrás Cubells), Centro de Estudios Históricos Internacionales, Barcelona, Universidad de Barcelona / Teide, 1953 [Stanford University Press, 1951]; Greene, R., Las 48 leyes del poder (edición de Joost Elffers, traducción de Ana Bustelo y César Vidal), Madrid, Espasa, 1999 [Penguin Books, 1998]; Kagan, R., Poder y debilidad (traducción de Moisés Ramírez Trapero), Madrid, Taurus, 2003; Loperena, J. M., El poder desnudo. Crónica de sátrapas, reyezuelos y otros redentores de la humanidad, Barcelona, Octaedro, 2013. Pese a las sugerencias, recordaremos una oración: el único poder es la mente, tema que es analizado por Punset 2010, op. cit. (nota 66). Y, respecto al "único poder", volvemos a llamar la atención sobre la referencia, quizá desde otro punto de vista, de Gazzaniga 2012, op. cit. (nota 65). Por otra parte, como sostenía Gonzalo Torrente Ballester, "el tema del poder y el tema del mito van aliados. [...]. Hay una especie de carrera tras el poder y al mismo tiempo yo veo cómo se elabora el mito". Y el poeta Francisco Castaño dirá, estando de acuerdo Torrente Ballester, que el poder "necesita de los mitos para tener una legitimación más allá de la fuerza". Puede verse en Castaño 1996, op. cit. (nota 106), pp. 77-78.

110 Sobre ello, puede ser interesante consultar la «actualidad» en Petit, Q., «Enganchados al porno "on line"», El País Semanal, Madrid, El País, 27 de abril de 2014, pp. 30-39.

111 Aramburu, F., «Pesca de usuarios», El Cultural, Madrid, El Mundo, 25 de abril de 2014, p. 11. Tan atrapados estamos en la red, que los fiscales especialistas en delitos informáticos no pueden investigar, por ejemplo, la red TOR: esos sistemas de «anonimización», en la red, que evitan los rastreos informáticos. La legislación procesal criminal española, obsoleta -ley de enjuiciamiento criminal del año 1982-, necesitaría actualizarse, para «librarse», por ejemplo, de esta red que "nos tiene a todos atrapados".

112 Wagner, R., Tristano e Isotta (Tristan und Isolde). Orquesta y Coro del Festival de Bayreuth (director: Karl Böhm), Milano, Europa Musica / Frequenz, 1987 [grabación del Festival de Bayreuth, en 13 de agosto de 1966]. (CD)

113 También, Alfonso X "tenía aproximadamente cuarenta y cinco años [de edad] [...] cuando concibió la idea de componer una colección de cien cantares a la Virgen", como explica Rey 2000, op. cit. (nota 77), p. 6. 
como, así, nos lo manifestaron algunos espectadores que asistieron a las funciones. El hecho de contar, en el escenario, con una Margarita de poco más de catorce años de edad114, también, nos ha permitido «visitar» las profundidades íntimas de cualquier Fausto contemporáneo que pudiese encontrarse entre el público. ${ }^{115}$

Resulta curioso observar que nuestros objetos, nuestras obras, podrán permanecer cuando ya no existamos. Y esta reflexión tiene que ver con el concepto elevado de toda obra de arte; que supera al creador y que es momentáneamente perenne y puede seguir viva tras la muerte del padre. Es la trascendencia en el tiempo; tiempo que, para Mefistófeles, no existe.

Fausto, de Goethe, ha sido considerado, por algunos, la Biblia laica; al menos, desde 1894116. En este «conjunto de libros», podemos entender que es imposible que las naciones estén de acuerdo, si los ciudadanos no pueden, siquiera, llegar a un acuerdo entre sí. 117

Decía el director de escena Juanjo Granda, cuando en 2008 escenificó Historia del soldado, de Igor Stravinsky, que el diablo "está dentro de nosotros, es nuestra parte negativa que nos conduce a la pérdida de valores y conciencia"118. Así pues, visto lo que acontece en nuestro alrededor contemporáneo, podemos hallarnos, hoy, «endiablados».

114 "Margarita tiene más de catorce años, pero pocos más", dice Sáenz, M., «Urfaust», Fausto, 5 (2006), Madrid, OCNE, 2006, p. 67. Véase que este modelo «mítico» se ha reproducido después, cuando Vladimir Nabokov escribe Lolita, en 1954; y cuando Stanley Kubrick lleva a la pantalla "el deseo de un hombre de 39 años [de edad], Humbert Humbert, por Lolita, una niña de 12 [años de edad]", en su producción cinematográfica de 1962. Véase Nabokov, V., Lolita (traducción de Enrique Tejedor), Barcelona, Anagrama, 2001 (decimoquinta edición) [Paris, 1955]; también, Duncan, P., Stanley Kubrick. El poeta de la imagen 1928-1999 (traducción del inglés de Meritxell Tena i Ripollés), Köln, Taschen, 2011, p. 73. El estreno de Lolita, de Kubrick, se produjo en 13 de junio de 1962, y como, quizá, no podría ser de otro modo, "en Nueva York tras arduas batallas con la censura británica y la Iglesia católica" - conviene recordar que el film La naranja mecánica, de Kubrick, se proyectó en el Reino Unido, iy desde 1974!, en el año 2000-, como puede verse en Duncan (2011), op. cit. (nota 114), pp. 186-187.

115 Como recordaría cualquier lector de este ensayo, que hubiera asistido a alguna de nuestras representaciones, la visión de las nalgas de una joven Margarita, de quince años de edad, produjo un fuerte impacto entre el público, cuando Fausto, a hurtadillas, levantaba el vestido de su fainomérida elegida. Así nos fue manifestado, igualmente, en el encuentro que, con el público, mantuvo la Compañía artística después de una de las últimas representaciones. Sobre este asunto, nos remitimos, también, a la referencia cinematográfica de Ozon 2013, op. cit. (nota 106).

116 Fue el título de un tratado: El Fausto de Goethe, considerado como Biblia laica (1894), como cita Schöne 2006, op. cit. (nota 85), p. 35.

117 Así mismo, lo expuso Goethe en 1827. Y, sobre la imposibilidad del acuerdo, puede consultarse el diálogo entre Sócrates y Alkibiades, que se encuentra, como apócrifo, en Diálogos de Platón. Quizá, esta "imposibilidad del acuerdo", esté vinculada con el afán de poder.

118 Granda, J., «Una "Historia del Soldado" teatral y reflexiva», La historia del soldado, de Igor Stravinsky, Madrid, OCNE, 2008, p. 3. La "pérdida" de unos valores heredados, por haberlos puesto en tela de juicio, no supone abandonar cualquier tipo de valor que nos aleje de la con $(s)$ ciencia de nos, sino, sólo, la sustitución, de los principios y valores heredados, por otros más conscientes. 
Nuestro Urfausto no es, exactamente, el Fausto de Marlowe ni el de Pfitzer ni el de Goethe ni el de Bulgákov ni el de Sokurov. Bebe -mucho- de las fuentes citadas, pero pretende una narración distinta en algo; trata las pasiones humanas de la tradición, pero entendemos que aborda, también, cuestiones que permanecen, aún, sin ser resueltas por el ciudadano metropolitano del siglo XXI, una vez superado «el siglo de la Muerte»119. Tal vez, por lo expuesto, recobre, este mito, la actualidad que, quizá, nunca perdió. Porque el medievalismo vital, el neofeudalismo económico, parece que necesitan de las creencias para refundarse en el hoy, y están reproduciendo nuestro pasado inmediato, nuestro pasado más atroz, nuestros mitos. El ahora perpetuará, quizá, y en tiempos venideros, los sistemas de dominación y de castración que impidan a los contemporáneos gozar de sus existencias, mientras sigan seducidos y abducidos por cantos de sirenas que prometan «otras» vidas, a cambio de hipotecarse ésta. El Fausto contemporáneo puede ser un individuo que ha vendido su alma al dios elegido, a un dios cualquiera de los muchos que se ofrecen en el mercado, a cambio de una hipoteca, también cualquiera, que se les antoje -de un mismo modo, este dicente tiene una hipoteca-, que podrá canjear en otra vida postrera, si la hubiere. En el fondo, esta hipoteca es un valle de lágrimas.

Como los cristianos, Fausto, después de todo, desprecia "nuestro único bien verdadero: la vida terrena" 120 -aunque la haya gozado haciendo el mal, gracias a

$119 \mathrm{Si}$ es de su interés, pueden consultar un ensayo que confirma la barbarie, estadísticamente insuperada, que identificó al siglo XX; en Thomas, L.-V., La muerte. Una lectura cultural (traducción de Adolfo Negrotto), Barcelona, Altaya, 1999. Por cierto, se trata de un ensayo que invita, a su vez, a abandonar la arrogancia del minúsculo homo sapiens -en Francia, mueren 65 personas por hora, y 560.000 al año-. "Cada uno de nosotros sabe también que ha de morir un día, pero nadie lo cree realmente", dice Thomas en la p. 10 del ensayo citado. Además, en el año 2013, parece que se han suicidado, sólo en España, alrededor de 3.500 personas. En 2008, el INE (Instituto Nacional de Estadística, de España) ya había registrado 3.421 suicidios, de 40.000 intentos. "Una cifra superior a los muertos por accidentes de tráfico. A pesar de la dureza del tema [Louis] Malle se atrevió a rodarlo hace casi cincuenta años", arguye Quintanilla 2010, op. cit. (nota 93), p. 12.

120 Onfray 2006, op. cit. (nota 66), solapa de la cubierta. Sin embargo, nos parece que existen muchas contradicciones en individuos cristianos, de fervor demostrable, en los que se produce una celebración por la vida, que nos sorprende. Así le sucedía a Olivier Messiaen, cuando, tras haber estado en un campo de prisioneros de Silesia, durante la Segunda Guerra mundial, compuso su Sinfonía Turangalîla en 1948-1949. Esta obra, cuyo título procede del sánscrito -y es una palabra compuesta: turanga (movimiento, tiempo, ritmo) y lîla (acto, acción)-, pretende una celebración de la vida, una fiesta. De hecho, la contradicción cristiana se observa en que la palabra, que titula la sinfonía, significaría "creación”, "destrucción", "vida”, "muerte”. Además, según James Hurding, esta obra es "entendida por Messiaen como su propia versión de Tristán e Isolda" (traducción del autor de este artículo), como puede verse en «Messiaen: Turangalîla Symphony», Messiaen. Turangalîla Symphony. London Symphony Orchestra (director: André Previn), Holland, Forte / EMI Classics, 1997, p. 4 (CD). Y nos parecen muy relevantes las imágenes que Peter West utiliza para ilustrar la obra de Messiaen. Las imágenes, así como unos comentarios de sir Simon Rattle, pueden verse en West, P., «Rhythm», Orchestral Music Orchestral Music in the 20th Century. City of Birmingham Symphony Orchestra (director: Sir Simon Rattle), Colección Leaving Home, vol. 2, Leipzig, Arthaus Musik, 1996. (DVD) 
Mefistófeles/Fausto-, y, por tanto, no la merece; así pues, debe perecer. Y se arrepiente de haber utilizado a Margarita, para satisfacer su capricho de recuperar la juventud y convertirla en eterna. Margarita es denostada, vilipendiada, repudiada, sacrificada121, como si fuese Lucrecia, violada por todos nosotros; otra víctima de varios estupros, como Helena de Troya122: la puta de la Historia, la zorra sin juicio $^{123}$. Con la oferta de las fainoméridas ${ }^{124}$, Fausto acepta su disfrute, gracias al elixir de la eterna juventud, y lo hace a costa de estas mujeres (Margarita y Helena); mujeres que, siendo tratadas como objetos ${ }^{125}$, cargarán con la culpa del hombre $-\mathrm{y}$

121 Estamos acordándonos del argumento que Igor Stravinsky plantea en su ballet La consagración de la primavera.

122 Como dice Salvador Mas, la "presencia de Helena en la historia de Fausto no es invención de Goethe. Aparece [...] en [la obra] [...] de Nikolas Pfitzer", de 1674. Puede consultarse Mas, S., «Helena y Fausto. Paralipomena para el Fausto II», Fausto, 5 (2006), Madrid, OCNE, 2006, p. 77.

123 Léase el monólogo Juicio a una zorra -exquisitamente interpretado, y estrenado en su momento en el Festival de Teatro de Mérida, por Carmen Machi-, escrito por Arco 2012, op. cit. (nota 100), pp. 93-104. "Habría que revisar, seriamente, quién escribe la historia", dice Miguel del Arco, a través de Helena de Troya. El resumen mitológico que ofrece Miguel del Arco reconstruye los abusos sexuales a los que fue sometida Helena de Troya. Este mito, se reproduce en la Historia -puesto que, como hemos dicho, la funda-. Pondremos dos ejemplos muy alejados en el tiempo. El primero, nos remite a finales del siglo VIII, cuando el papa León III es acogido y protegido en Sajonia por Carlomagno, después de haber sido "maltratado por los romanos", por ser acusado de adulterio, perjurio y abusos sexuales. El final de esta historia es conocido: Carlomagno será coronado por León III - ¿como agradecimiento por la protección recibida?-, en el año 800, Augustus Emperator Romanorum. Y el segundo ejemplo, se refiere al papa cristiano católico actual, Jorge Mario Bergoglio, alias Francisco, que, en 2014, pide "«perdón humildemente por los pecados y crímenes graves de abusos sexuales cometidos por el clero. También por los pecados de omisión por parte de los líderes de la Iglesia que no han respondido adecuadamente a las denuncias presentadas»". Algunas de las víctimas "no encontraron otra salida que las drogas o el suicidio". Como observamos, parece que seguimos «rodeados» de Faustos y Margaritas. Los comentarios citados, pueden leerse en Ordaz, P., «El Papa: "Pido perdón humildemente por los abusos sexuales del clero"», El País, Madrid, El País, martes 8 de julio de 2014, p. 34. Como «antecedente» de los hechos, y de la «denuncia» de éstos, citamos el libro de Rodríguez, P., $L a$ vida sexual del clero, Barcelona, Ediciones B, 1995.

124 Podemos establecer un paralelismo entre las «mujeres que enseñan los muslos» y las mujeres bacantes, que Apolo ofreció a su hijo Orfeo, al haber perdido, este último y para siempre, a su amada Euridice. El rechazo de Orfeo, ante tal oferta, le distancia de Fausto, aunque su final acabe siendo igual de trágico, o más, que el de nuestro protagonista. Y es que, para la señora de la guadaña, no importa lo acontecido en el tránsito hacia ella; no distingue.

125 Mucho se ha criticado a Hugh Hefner, creador de la revista Playboy, por utilizar los cuerpos de las mujeres como objetos de reclamo erótico y sexual. Él mismo defendía el cuerpo de la mujer como un objeto visual, de reclamo visual. Para muchos, Hefner ha sido un luchador por la libertad de expresión en los Estados Unidos de Norteamérica, desde 1954. Puede verse un documental, sobre la vida de Hefner y la creación de Playboy, en Berman, B., Hugh Hefner, Canada, 2010. Este documental, fue visto en TVE 2, a las 0,30 horas, en 20 de julio de 2014. Un caso similar podría ser el de Benedikt Taschen, a través de su revista Taschen, fundada en 1980, y en la que las imágenes del cuerpo de la mujer y del hombre -como objetos visuales: imágenes- representan, con natural normalidad, el erotismo y la sexualidad. La primera edición en castellano, de la revista Taschen -con un tamaño ligera- 
con sus hijos-126: será más fácil, ahora, acusarlas -y a otras cualesquiera- de brujería y maleficio127. Es el poder ejercido sobre las mujeres, como una Dido de Cartago o una Madama Butterfly. Éstas, son cuestiones que no ha resuelto el ciudadano metropolitano del siglo XXI: el poder ejercido sobre -y contra- las mujeres; el poder que las relega del poder. Es la gran estafa; la estafa que perpetra Fausto, con las vidas sesgadas de Margarita (estafa de Fausto) y de Helena (estafas de Teseo, Menelao, Paris, Deífobo...); como la estafa monetaria de la Gran Recesión actual que llaman crisis económica: "El 90\% de lo que se llaman crisis económicas son estafas monetarias", dice Antonio Escohotado. Para algunos, no se trata de una “crisis global”. ${ }^{128}$ Nos parece, por tanto, que la Gran Recesión actual (crisis econó-

mente más pequeño que las ediciones anteriores en inglés-, la encontramos en Taschen, B. (prod. y dir.), Taschen (traducción al español de LocTeam, Barcelona), Köln, Taschen, 2014, primavera de 2014. Ambos casos contemporáneos -Hugh Hefner y Benedikt Taschen-, podrían ser unos adalides de la escritura y la imagen, en los siglos XX y XXI -como lo fueron Hildegard von Bingen y Alfonso X, respectivamente, en los siglos XII y XIII-.

126 En este sentido, traemos, a colación, las palabras de Natividad Massanés, como prologuista y coescritora de la biografía de Felicidad Blanc - esposa de Leopoldo Panero y madre de los Panero, cuya explícita posición entre hombres fue expuesta por Jaime Chávarri, en el desolador documental titulado El desencanto-: "Dos mundos, pues, para una sola humanidad. El mundo de la libertad, en el que el ser humano se hace a sí mismo, para el hombre; el mundo de las leyes inmutables en el que la biología es el destino, para la mujer. La mujer, fósil humano: igual hoy que en la prehistoria. Ésos son, en definitiva, los supuestos en que se ha basado la civilización occidental para justificar el relegamiento social de las mujeres, en todas las épocas, a un segundo plano. Para someter a uno de los sexos, las hembras, a los intereses y necesidades del otro sexo, el único plenamente humano: el hombre”. Puede verse en Blanc, F. y Massanés, N., Espejo de sombras, Barcelona, Argos Vergara, 1977, p. 7. También, en la edición publicada en Barcelona, Cabaret Voltaire, 2015 (pp. 11-16).

127 Sobre este asunto, quizá sea oportuno acercarse a las obras, capítulos y artículos de Álvarez Junco, J., «Magia y ética en la retórica política» (Populismo, caudillaje y discurso demagógico); de Quaife, G. R., Magia y maleficio. Las brujas y el fanatismo religioso; de Moore, R. I., La formación de una sociedad represora; de Bennassar, B., Inquisición española: poder político y control social; de Elorza, A., «El temido árbol de la libertad» (España y la revolución francesa); etc. Y por dar actualidad al caso, también puede profundizarse en las vivencias de las mujeres españolas, acusadas de todo tipo de culpas durante la represión franquista, a través del documental de Pérez Solano, P., Las maestras de la República, Madrid, FETE-UGT/Transit, 2013. (DVD)

128 Al citar a Dido y a Madama Butterfly, sin poder remediarlo, estábamos acordándonos de Henry Purcell y de Giacomo Puccini, respectivamente; también, de Marlowe, que escribió La tragedia de Dido, reina de Cartago, estrenada en 1593. El concepto Gran Recesión, para referirse a la crisis actual, es utilizado por Manuel Castells, relacionándolo con "la Larga Depresión de 1873 y la Gran Depresión de 1929". Dicen que "si de ambas salió fortalecida la sociedad, ¿por qué no habría de suceder lo mismo en la actual?", como puede verse en Sarabia, B., «Después de la crisis», El Cultural, Madrid, El Mundo, 10 de enero de 2014, p. 23. Y en el caso particular español, éste, se nos describe "como el escenario de una profunda crisis moral, ética e institucional", según Sarabia, B., "Qué hacer con España. Del capitalismo castizo a la refundación de un país», El Cultural, Madrid, El Mundo, 4 de octubre de 2013, p. 13. Otras estafas fueron las de Egisto, Norris, Paolo, Buckingham, Beltrán de la Cueva, etc., como nos recuerda Sokurov 2011, op. cit. (nota 75) (DVD). En cuanto a la cita de Antonio Escohotado, ésta, puede verse en Arjona 2013, op. cit. (nota 91), p. 10. 
mica), pudiendo partir, como estafa, de sisas pecuniarias, hundiría sus raíces en una crisis ética, y podríamos enmarcarla, entonces, como un hecho fáustico, y mítico.

El trasunto del poder, en su vínculo fáustico, también lo encontramos en el abjurador jesuita Cristovao Ferreira: “¿La religión? Una invención de los hombres para asegurarse el poder sobre sus semejantes"129, a lo que añadiríamos, como matiz, «o sea sobre las mujeres». Una leve muestra de la corrupción que ejerce el poder, sobre los que lo detentan -sea éste absoluto o no, pues, que el poder corrompa, es una característica intrínseca, implícita, a la propia detención del poder, y no tanto a la cantidad o/y calidad de este último-, quizá sea que Fausto no anhela los labios de Helena por sí mismos -o en sí mismos-, pues no quiere "besar unos labios, sino el surco dejado en ellos por bocas de leyenda."130 Empero, nada de eso parece que, hoy, importe demasiado. Fausto, como hemos dicho, se arrepiente; quiere salvar a Margarita. Para nosotros, es demasiado tarde. Aplicamos, así, el juicio de Tirso de Molina con Don Juan -en la atribución sobre El burlador de Sevilla-, frente al «benévolo» veredicto de José Zorrilla -en eso, no somos nada románticos-. Fausto debe sucumbir, porque, sólo así, habremos mostrado que lo único que queda es la concepción pragmática del Homo homini lupus de Thomas Hobbes. Muerto, ya, el Fausto del fasto, queda el otro Fausto, creado por él mismo: Mefistófeles, el verdadero sobreviviente. Tras la desaparición, sólo permanece la obra de arte: literaria, musical, plástica. ¿Quién recuerda a los potentados y políticos de tiempos de Shakespeare?, ¿quién sabe de los Lehman Brothers de la época de Velázquez?, ¿alguien ha memorizado algún ministro de Economía de tiempos de Johann Sebastian Bach? Sin embargo, en las Españas, el IVA (Impuesto sobre el Valor Añadido) para la cultura es del 21\%131 - Cultura que es "una capa muy fina, aun-

129 Puede verse en Onfray 2006, op. cit. (nota 66), p. 46.

130 Molina Foix 2006, op. cit. (nota 5), p. 130.

131 En la actualidad del año 2016. Traemos, a colación, un comentario de Ana María Leyra, cuando se refiere al libreto operístico de la obra Mito, de Antonio Buero Vallejo: "los españoles, demasiado preocupados en ser vascos, catalanes o gallegos, pero indiferentes ante la necesidad de ser pueblos cultos, un lamentable caso de sordera cultural". Puede verse en Leyra 2006, op. cit. (nota 55), pp. 134135. Gonzalo Torrente Ballester decía que "probablemente el español es el peor lector del Quijote que hay". Francisco Castaño nos remite a una imagen de un chiste, "en el que se veía a un español arrojando al suelo El Quijote mientras airadamente le decía: ¡usted no sabe quién le está leyendo!". Torrente Ballester argüía que "esto explica gráficamente la respuesta del español ante El Quijote"; cree que se ríen de él. "El español no admite que le tomen el pelo, y El Quijote es una tomadura de pelo". El español no sigue la corriente, no juega con «esas cosas», y, por ello, "lo arroja, lo patea. Pero como el mundo le dice al español que es una obra maestra y que es una gloria nacional, entonces se dedica a la erudición", que, como comparte Francisco Castaño con Torrente Ballester, "es la forma más estéril de lectura" -quizá no se refiera a una obra como Vida de Don Quijote y Sancho, de Miguel de Unamuno [¿lo es, acaso, este ensayo nuestro?]-. Puede verse en Castaño 1996, op. cit. (nota 106), p. 80. Quizá, como hiciera Thomas Bernhard con su Austria natal -pensamos, sobre otras, en su obra Tala (versión española de Miguel Sáenz), Madrid, Alianza, 2002 [Frankfurt am Main, 1984], y en "Como no he conseguido hacer más sensatos a los hombres, he preferido ser feliz lejos de ellos", que 
que importante, que recubre la biología"132; la cultura, será lo único que nos trascienda, y que, por tanto, perdure y hereden nuestros descendientes. Así pues, nos parece que lo verdaderamente humano, sólo, es la cultura; el resto, mamífero animal. Las revistas pornográficas, como sabrán algunos, tienen, según los casos, un IVA del tres, o del cuatro, por ciento-133. Mefisto, es la gran obra de Fausto; de su acedia. El alter ego, verdaderamente artístico, pensamos que es inmortal ${ }^{134}$.

\section{Conclusiones}

Les comunicamos, como una conclusión, que cabe la posibilidad de que los hechos narrados hayan ocurrido, e, incluso, que se estén re-produciendo (sic), por

dijera François-Marie Arouet, alias Voltaire, y que cita el propio Bernhard en la p. 7 de Tala-, Antonio Escohotado también, con cierta similitud, "describe a España en el siglo XIX como el país europeo más inclinado al odio mutuo", como recoge Arjona 2013, op. cit. (nota 91), p. 10. Y otro caso más, de alguien "empeñado en que España podía ser un país digno y habitable", es el de Eugenio Noel (18851936), que puso "sal y pimienta en las llagas de las heridas patrias", en su intento por revivir "ese cadáver hediondo de una España devorada por gusanos obispos, gusanos militares, gusanos terratenientes, gusanos flamencos, gusanos toreros", como "sus hombres de Estado (homúnculos de Estado, los llama Noel)" -que nos recuerdan al homúnculo que Wagner, el ayudante de Fausto, crea, y que se ve en el film de Sokurov 2011, op. cit. (nota 75) (DVD)-. Como sigue diciendo José Luis Moreno-Ruiz, en el libro de Noel, "la zafiedad nacional alcanza cotas de miseria semejantes a las de otras épocas (a las de siempre, en realidad) [...]: puede acabar uno solicitando la nacionalidad lituana, por ejemplo, o haciendo votos para que Cataluña tenga pronto su independencia y así naturalizarse allí" -observemos que, esto último, es escrito en el año 1995, casi veinte años antes de que Cataluña pusiera fecha, finalmente, a su consulta popular, para que los catalanes manifestaran si deseaban, o no, su independencia de España, y que celebraron en 9 de noviembre de 2014, haciéndolo coincidir con el tercer centenario de su pérdida de autonomía, por no haber apoyado al primer Borbón en España: Felipe V, en 1714, tras la Guerra de Sucesión-. Todo esto, puede leerse en la presentación que José Luis Moreno-Ruiz hace de Noel, E., Escenas y andanzas de la campaña antiflamenca, Madrid, Libertarias / Prodhufi, 1995, solapa y pp. 11-12. El mismo Eugenio Noel dice: "Viendo bailar a esta mujer se concibe que España lleve seis siglos de retraso a [(sic)] los demás pueblos en su civilización" (p. 243).

132 Así lo señala el paleoantropólogo Juan Luis Arsuaga, en entrevista de López Rejas, J., «La cultura es una capa muy fina que recubre la biología», El Cultural, Madrid, El Mundo, 12 de julio de 2007, p. 58.

133 Esta idea, es compartida por Luis María Anson, quien ha escrito varios artículos en torno a dicha crítica, siendo, los últimos, los siguientes: «Las revistas porno, 3\% de IVA; representar a Calderón, 21\%», El Cultural, Madrid, El Mundo, 11 de octubre de 2013, p. 3; «La cultura en el desván», El Cultural, Madrid, El Mundo, 6 de junio de 2014, p. 3; también, con referencias en «Madrid, el esplendor en el teatro», El Cultural, Madrid, El Mundo, 16 de mayo de 2014, p. 3.

134 Salvo que se produzcan cataclismos, como el acontecido hace sesenta y cinco millones de años. Es "todo lo que queda cuando no queda nada; [...] la aceptación tranquila de lo absurdo de todo. [...]; la exaltación justo antes de la nada, la muerte [...]. Sólo la nada. La inmovilidad del protagonista" del film La grande bellezza, de Paolo Sorrentino. "Como [le sucede] al príncipe Don Fabrizio Salina en El gatopardo", la obra de Giuseppe Tomasi di Lampedusa; y en el film del título homónimo, de Luchino Visconti. El texto citado, puede leerse en Martínez, L., «La bellezza según Sorrentino», El Cultural, Madrid, El Mundo, 29 de noviembre de 2013, pp. 44-45. 
repetirse hoy. Asimismo, nos lo recuerda Mijaíl Bulgákov, en el epílogo de su obra: "Pues sí, pasaron varios años y los verídicos sucesos relatados en este libro se fueron olvidando, apagándose poco a poco en la memoria. Pero eso no les sucedió a todos. Cada primavera, en cuanto llega la luna llena de fiesta, bajo los tilos [...] aparece al atardecer un hombre de unos treinta años. Tiene el pelo rojizo. [Otro, recuerda que] en su juventud fue víctima de una panda de hipnotizadores, que luego estuvo en tratamiento y consiguieron curarle"135. También, parece que "en Moscú dos mil personas habían salido del teatro completamente desnudas, y con esa pinta tuvieron que irse a sus casas en taxis. El susurro «el diablo» se oía en las colas de las lecherías, tranvías, tiendas"136. Por tanto, colaboramos para que los hechos ocurridos no se olviden.

¿Fausto es un insatisfecho insaciable?, ¿lo somos nosotros? Piensan los budistas que el deseo acaba siendo una fuente de infelicidad. Como sugería Salvador Dalí, podemos "contribuir al descrédito total del mundo de la realidad"137, con un único fin: "hacer tambalearse la fe inquebrantable en lo que denominamos el mundo real." 138

Debemos reconocer que hemos sido muy cobardes 139 , por no habernos atrevido a situar este Fausto en nuestra época, en la actualidad -escándalos, los justos-. Pero el espejo sigue siendo válido: «lean entre líneas», mírense en él, si tienen arrojo 140 , y hagan las adaptaciones contemporáneas que estimen adecuadas. Finalmente, no podemos negar que hemos sido objeto de todo tipo de vilipendios, por querer escenificar este mito. ${ }^{141} \mathrm{Al}$ respecto, nos preguntamos, y sobre la formación de nuestros jóvenes, ¿cuándo, si no en su educación Secundaria -y pensando en que estudiaran, con seriedad, profundidad y rigor, Literatura universal o/y Filosofía-, iban a poder conocer el mito de Fausto, y otros? Para que, en el futuro,

\footnotetext{
135 Bulgákov 2010, op. cit. (nota 63), pp. 471-472.

136 Ibidem, p. 463.

137 Es una cita de Leyra 2006, op. cit. (nota 55), p. 205.

138 Ibidem

139 Cobardes, nos parece que son muchos, sobre todo algunos de los que sobreviven en las guerras; los que, luego, nos las cuentan, aunque no hayan estado en la primera línea de fuego. Y, al final, la historia de las guerras siempre será, quizá, la transmitida por los que no las combatieron. ¿Quién escribe la historia? Aforísticamente, deberíamos contestar: «los cobardes».

140 El que le faltó a Angel Heart, en el film de Parker 2001 [1987], op. cit. (nota 94). (DVD)

141 Además, sepan que hemos percibido mucho miedo, en individuos que, de uno u otro modo, supieron que queríamos representar nuestro Urfausto. Hemos notado que la psicología social de antaño, sometida al yugo providencial, nos resulta muy contemporánea. Los fantasmas siguen atenazando a individuos que se encuentran en la decena entre los cuarenta y cincuenta años de edad; individuos actuales, que nacieron entre los años 1965 y 1975. Esto, hemos ido percibiéndolo en el corto devenir de nuestros encuentros y desencuentros, en la temporada 2013-2014. Hagan las lecturas e interpretaciones que consideren: jes asombroso! -e inconcebible-: volvemos; por donde solíamos no ha mucho tiempo. ¡Una lástima!
} 
a nuestros adultos - dirigentes, políticos o/y administradores de la res publica, de cualquier estirpe o familia, acreedores o no de una ideología; con poder-, no les resulte ignoto, hemos de darles, a nuestros jóvenes de hoy, la oportunidad de conocer las señas de identidad de su civilización -igual que hacemos con La Celestina $^{142}$, con Don Quijote o con Don Juan, pongamos por casos-. En la enseñanza Secundaria, tenemos, prácticamente, la última oportunidad para extender, a una población no erudita, el conocimiento acerca de las raíces de nuestro modo de concebir la existencia: la Cultura, y, especialmente, el Arte actual.

No debería preocupar a nadie que no se entendiera todo lo que, escénicamente, narramos; un público diletante, no profesional, se «quedó» con los aspectos «visuales», si les parece; con las imágenes. Comprendemos que, viviendo rodeados de tanto aparato tecnológico, a su disposición y de su dominio -teléfonos portátiles hiperinteligentes, tabletas dáctiles interactivas, ordeñadores (sic) de información pirateada, macropantallas de visualización exclusiva, televisores digitales terrestres, etc.-, seguramente, y por estar habituados, captaron aquello que fue explícito. Lamentamos, no obstante, que perdieran el contenido implícito; contenido que, en la profundidad, les fue -sólo-sugerido.

Observen que -como, al parecer, decía el hispano neerlandés Baruch de Spinoza, iy en el siglo XVII!- "los derechos del cuerpo, tanto como los deberes del alma, se ven hoy día como una senda sin recorrer en la sensibilidad moderna."143 El debate más caro del cristianismo, que escenificó Emilio de' Cavalieri en el año 1600, es el que permanece vivo en nuestra interpretación del mito de Fausto: la contradicción entre las aspiraciones del Alma y las tentaciones del Cuerpo, junto a los que, en la obra Rappresentatione di Anima et di Corpo, Cavalieri acompañó de otras tantas alegorías fáusticas: el Tiempo, el Intelecto, el Consejo y el Placer. ${ }^{144}$ Quizá, como oímos decir al estadístico sueco Hans Rosling, al final, "el problema no es la ignorancia, sino las ideas preconcebidas."'145

142 Aunque, como nos apunta el doctor Francisco Javier Gómez Martínez, se trate de una Celestina "edulcorada".

143 Parreño, J. M., «El luthier de Delft. Música, pintura y ciencia en tiempos de Vermeer y Spinoza», El Cultural, Madrid, El Mundo, 13 de diciembre de 2013, p. 33.

144 Sobre esta dualidad, puede consultarse D’Ors, E., «Estudio preliminar. Tríptico de Goethe. I: El olímpico», Fausto (traducción de José Roviralta Borrell), Clásicos Jackson, vol. XVII, Barcelona, Éxito, 1951, p. XI. También, con una relación tangencial, pueden revisarse los estudios de Jean-Luc Nancy, sobre "El cuerpo y las artes". Puede verse Cavalieri, E. de', Rappresentatione di Anima et di Corpo (director: Lorenzo Tozzi). Gasdia, Zanasi, Stoch, Staccioli, Rossetti, Bassani. Coro Lírico Sinfónico Romano (director: Stefano Cucci), Romabarocca Ensemble. Orquesta Sinfónica del Festival de Pascua, Barcelona, Planeta, 2008 (DVD). Y estamos recordando la relación entre el alma cristiana -como resultante vencedora tras la muerte- y el cuerpo -como depositario de la vida-, en la pieza Combat de la Mort et de la Vie, de la obra Corps glorieux, para órgano, de Olivier Messiaen.

145 Es una idea divulgada en el programa Redes y dentro del Canal 24 horas de la Televisión española. El programa fue emitido en 18 de septiembre de 2010, a las 11,00 horas. 
Siguiendo, en su día, el consejo de Rafael Lapesa Melgar, nos hemos sentido herederos de una literatura dramática próxima a El condenado por desconfiado y a La verdad sospechosa, como, quizá, haya podido ser evidente. 146

Deseamos que la tradicional maldición, que persigue a quienes se atreven a presentar este tema tan europeo, no se encapriche de nuestros pescuezos -pues Fausto es dueño de Mefisto-. Durante nueve meses estuvimos pasando miedo; de distintas formas, de distintas maneras y de distintos modos: forma, manera y modo -del miedo-; ahora, les tocará a otros. Nuestro deseo fue, para los que lo vivieron, que lo «disfrutaran»-si es que pudieron-.

\section{NVNC ET IN HORA MORTIS NOSTRA}

\section{Otras fuentes documentales utilizadas para la dramaturgia147}

Anson, Luis María: "Camus o el único problema serio: el suicidio". En: El Cultural. Madrid: El Mundo, 25 de octubre de 2013, p. 3.

Anson, Luis María: "Quédate con nosotros, Señor, porque atardece". En: El Cultural. Madrid: El Mundo, 31 de enero de 2014, p. 3.

ARmStrong, Louis: Best of. Barcelona: Divucsa, 1993 [Prestige Records, 1992]. (CD)

BÉCQUeR, Gustavo Adolfo: Leyendas. Moby Dick. Biblioteca de bolsillo junior. Barcelona: La Gaya Ciencia, 1978.

Bernhard, Thomas: Goethe se muere. Traducción del alemán de Miguel Sáenz. Madrid: Alianza, 2012 [Suhrkamp Verlag Berlin, 2010]. BerRiAtúA, Luciano: Los cinco Faust de Murnau. Divisa Home Vídeo, 2002 / 2013. (DVD)

BINGEN, Hildegard von: Symphonia armonice celestium reuelationum. Vivien Ellis, Jocelyn

\footnotetext{
146 En mayo de 1985, gracias al periodista y poeta José Antonio Azcano, tuvimos la oportunidad de entrevistar a Rafael Lapesa, en su residencia de la universidad Complutense de Madrid, con el que departimos sobre distintos problemas educativos. Y en el año en que se estrenó, en Madrid, el Fausto de Götz Loepelmann, Rafael Lapesa remitió una carta manuscrita, en septiembre de 1997, a la que entonces era ministra de Educación y Cultura: Esperanza Aguirre, en respuesta a la consulta de la ministra sobre el proyecto de reforma de los planes de estudio. En su carta, el doctor Lapesa incluyó las obras que hemos mencionado. Puede verse en un artículo dedicado a la memoria de Rafael Lapesa, en el año de su fallecimiento, del académico Ynduráin, D., «Lapesa, la generosidad de un maestro», El Cultural, Madrid, El Mundo, 7 de febrero de 2001, p. 3.

147 Las fuentes, no especificadas entre paréntesis, son bibliográficas. Además de las fuentes citadas a pie de página, las que se mencionan en este apartado, han sido utilizadas para crear nuestra obra dramática, y para realizar este breve ensayo.
} 
West, Sara Stowe (Oxford Girls Choir). Director: Stevie Wishart. Madrid: Glossa, 2001. (CD)

Boito, Arrigo: Mefistofele. Ópera en cuatro actos. Chorus and Orchestra of the San Francisco Opera. Director: Maurizio Arena. Samuel Ramey (Mefistófeles), Gabriela Benacková (Margarita/Helena), Denis O’Neill (Fausto). Director de vídeo: Brian Large. Madrid: Del Prado, 2005 [San Francisco: RM Arts, 1989]. (DVD)

Bosing, Walter: El Bosco. Entre el cielo y el infierno. Köln: Taschen, 2013 [Londres: Ingo Walther, 1973].

Bulgákov, Mijaíl: El maestro y Margarita. Reconstrucción de Marietta Chudakova. Versión de Marta Rebón. Prólogo de Ricardo San Vicente. Nevsky Prospects, 2014.

BuRTon, Richard y Coghill, Nevill: Doctor Faustus. Barcelona: Regia Films, 2011 [UK: Nassau Films / Oxford Univ., 1967]. (DVD)

ButLer, Elisabeth M.: El mito del mago. Cambridge: Cambridge University Press, 1997.

CAVAlieri, Emilio de': Rappresentatione di Anima e di Corpo. Frisan, Carmignani, Lepore, van Goethem, Abbondanza, Pentasuglia, Vargetto, Vaccari, Pennicchi. Capella Musicale di San Petronio di Bologna. Director: Sergio Vartolo. EC: Naxos, 1998 [grabación, en Francia, en 1996]. (CD)

CírCulo DE Lectores: Los 25.000 mejores versos de la lengua castellana. Barcelona: Círculo de Lectores, 1990, p. 250-252.

Comte-Sponville, André: El alma del ateísmo. Introducción a una espiritualidad sin Dios. Traducción: Albino Santos Mosquera. Barcelona: Paidós, 2006.

DomenÉch, Carmen y Gutiérrez, Santy: "La historia del soldado, de Igor Stravinsky". Traducción del texto, de Charles-Ferdinand Ramuz al libreto; y adaptación del libreto al cómic e ilustraciones, Carmen Doménech y Santy Gutiérrez, respectivamente. En: Orquesta y Coro Nacionales de España. La historia del soldado de Igor Stravinsky. Madrid OCNE, 2008.

Ellington, Duke: "Las joyas del Duque". En: El Gran Jazz. Madrid: Ediciones del Prado, 1995 [Milano: SAAR, 1994]. (CD)

EPICURO: Filosofia para la felicidad. Traducción de Carlos García Gual, Emilio Lledó y Pierre Hadot. Madrid: Errata Naturae, 2013.

FisCHER, Wolfgang Georg: Egon Schiele. Traducción de Carlos Caramés. Köln: Taschen, 2007.

FRANKIE GoEs To HOLLYWOOD: "The power of love". En: Welcome to the pleasuredome. UK: ZTT Records, 2010 [1984-1986]. (CD)

FundaCión JUAN MARCH (ed.): Otto Dix. Catálogo de la exposición, del 10 de febrero al 14 de mayo de 2006. Madrid: Fundación Juan March, 2006.

García Gual, Carlos: Epicuro. Madrid: Alianza, 1985. 
García Gual, Carlos: Diccionario de mitos. Madrid: Siglo XXI, 2003.

GARDInER, Sarah M.: Entre el amor y el sexo. Consejos y sugerencias para vivirlos.

Madrid: LIBSA, 1994.

GiBRÁn, Gibrán Jalil: El profeta. El loco. El vagabundo. El jardín del profeta. Arena y espuma. Traducción de Mauro Armiño. Madrid: Valdemar, 2006.

GIMBER, Arno: “Goethe o Wagner: ¿dos representaciones del espíritu alemán?”. En: Götterdämmerung. Richard Wagner. Madrid: Teatro Real, 2004, p. 127-134.

Goethe, Johann Wolfgang: Fausto. Traducción de José Roviralta Borrell. Estudio preliminar por Eugenio d'Ors. Clásicos Jackson, volumen XVII. Barcelona: Éxito, 1951.

Goethe, Johann Wolfgang: Faust. Edición bilingüe de Helena Cortés Gabaudan. Madrid: Abada Editores, 2009.

GonzÁlez FAus, José Ignacio: Herejías del catolicismo moderno. Madrid: Trotta, 2013.

HABERMAS, Jürgen: Entre naturalismo y religión. Traducción de Pere Fabra, Daniel Gamper, Javier Gil, José Luis López de Lizaga, Pedro Madrigal y Juan Carlos Velasco. Barcelona: Paidós, 2006.

Kechiche, Abdellatif: La vida de Adèle. Francia / Bélgica / España: Quat'sous Films y Wild Bunch, 2013. (CINE)

LACLOS, Choderlos de: Las amistades peligrosas. Traducción anónima (Barcelona, ca. 1835), revisada por Gabriel Ferrater. Barcelona: Círculo de lectores, 1990 [Les liaisons dangereuses. Paris, ca. 1782].

LampedusA, Giuseppe Tomasi di: El Gatopardo. Edición de Raffaele Pinto. Traducción de Fernando Gutiérrez. Madrid: Cátedra, 2006 [Giangiacomo Feltrinelli, 1958].

Le ClézIo, Jean-Marie Gustave: El éxtasis material. Traducción de Juana Bignozzi. Buenos Aires: Adriana Hidalgo, 2010 [Gallimard, 1967].

LIPOVETSKY, Gilles: El imperio de lo efimero. La moda y su destino en las sociedades modernas. Traducción de Felipe Hernández y Carmen López. Barcelona: Anagrama, 2011 [Gallimard: 1987].

LÓPEZ REJAS, Javier: “Álex Rigola: «He sentido una necesidad animal de adaptar a Bolaño»". En: El cultural. Madrid: El Mundo, 24 de enero de 2014, p. 38-39. López-REy, José: Velázquez. La obra completa. Köln: Taschen, 1998.

MAHLER, Gustav: Sinfonía $n^{\circ}$ 8. Royal Concertgebouw Orchestra. Director: Bernard Haitink. Philips, 1996 [grabación de 1971]. (CD)

MARlowe, Christopher: La trágica historia de la vida y la muerte del doctor Fausto. Traducción de Julián Jiménez Hefferman. Madrid: Abada, 2006.

Mauri, Albert y Ollé, Àlex (ed.): La Fura dels Baus / 1979-2004. Barcelona: Electa, 2004. (TEXTO y DVD)

Moreno Claros, Luis Fernando: "Luminosa oscuridad". En: Babelia. Madrid: E1 País, 24 de noviembre de 2012, p. 6. 
Murnau, Friedrich Wilhelm: Fausto. Divisa Home Vídeo, 2002/2013 [Alemania: 1926]. (DVD)

NANCY, Jean-Luc: El cuerpo y las artes. Conferencia ofrecida en Madrid, en el paraninfo de la Facultad de Filosofía de la UCM, a las 10,00 horas del día 23 de abril de 2012, transcrita a partir de apuntes de Cucho Valcárcel. (CONFERENCIA)

OCNE (ed.): Fausto. Madrid: OCNE, 2006.

OJEDA, Alberto: "Bill Viola: «Wagner libera mis emociones más profundas y ocultas»". En: El Cultural. Madrid: El Mundo, 10 de enero de 2014, p. 36-37.

PenDERECKI, Krzysztof: Seven gates of Jerusalem (Symphony n ${ }^{\circ}$ 7), for five soloists, speaker, three mixed choirs and orchestra (1996). Bozena Harasimowicz-Hass (soprano), Izabella Klosinska (soprano), Jadwiga Rappé (contralto), Wieslaw Ochman (tenor), Romuald Tesarowicz (bajo), Boris Carmeli (narrador), National Philharmonic Choir Warsaw (Henryk Wojnarowski, director), National Philharmonic Orchestra Warsaw. Director: Kasimierz Kord. Mainz: Wergo, 2000 [grabación, en Viena, en 1999]. (CD)

PolANSKI, Roman: Rosemary's Baby (La semilla del diablo). Madrid: Paramount, 2001 [Paramount, 1968. Estrenada, en España, al finalizar el año 1974]. (DVD) PozA, M. F.: "Prólogo". En: Fausto (Goethe). Madrid: Aguilar, 1983, p. 5-11.

SÁnchez LlaVe, Jesús: El podólogo. Cuento facilitado por el autor. Madrid: 2003. Schubert, Franz: Goethe Lieder. Vol. 2. Deutsche Schubert-Lied-Edition 13. Ruth Ziesak (soprano), Ulrich Eisenlohr (piano), Christian Elsner (tenor). EC: Naxos, 2003. (CD)

SCORSESE, Martin: La última tentación de Cristo. USA: Universal, 2003 [1998]. (DVD)

Sorrentino, Paolo: La Grande Bellezza (La gran belleza). Italia / Francia: Indigo Films, 2013. (CINE)

Stravinsky, Igor: Histoire $d u$ soldat. Texto de Charles-Ferdinand Ramuz. Traducción, al castellano, de Silvia López Sánchez. Carole Bouquet (narrador), Gérard Depardieu (diablo), Guillaume Depardieu (soldado), Pascal Moraguès (clarinete), Sergio Azzolini (fagot), Marc Bauer (trompeta), Daniel Breszynski (trombón), Vincent Pasquier (contrabajo), Michel Cerutti (percusión), Shlomo Mintz (violín y dirección). France: Auvidis, 1997. (CD)

THE BEATLES: "Revolution 9". En: White album. UK: EMI, 2009 [1968]. (CD)

The Real Book (ed.): The Real Book 1979. Totally Revised Edition 1979. New York: The Real Book Press-Syosset, 1979.

Toman, Ralf (ed.): El arte del Renacimiento en Italia. Colonia: Könemann, 1994. Trier, Lars von: Anticristo. Barcelona: Cameo Media, 2009 [Dinamarca: 2009]. (DVD)

VAlerA, Juan: El Fausto de Goethe. Edición de Leonardo Romero Tobar. Madrid: ELR, 2007. 
VISCONTI, Luchino: El gatopardo (Il gattopardo). Versión íntegra remasterizada. Madrid: Feel Films, 2013 [Francia / Italia, 1963]. (DVD)

WASSERMAN, Janet: www.carolinaclassical.com/faust/.

\section{Agradecimientos}

Dra. Elena Gento Peña, Profesor Dr. Francisco Javier Gómez Martínez, Evelio Montes López, Profesor Carlos Fernández Torres, Laurence Jude, Pilar Faneite Hernández, Profesor Hernán Jaén Diez 